This item was submitted to Loughborough's Research Repository by the author.

Items in Figshare are protected by copyright, with all rights reserved, unless otherwise indicated.

\title{
Controlled production of eco-friendly emulsions using direct and premix membrane emulsification
}

\section{PLEASE CITE THE PUBLISHED VERSION}

http://dx.doi.org/10.1016/j.cherd.2015.04.009

\section{PUBLISHER}

Elsevier / @ The Institution of Chemical Engineers

VERSION

AM (Accepted Manuscript)

\section{PUBLISHER STATEMENT}

This work is made available according to the conditions of the Creative Commons Attribution-NonCommercialNoDerivatives 4.0 International (CC BY-NC-ND 4.0) licence. Full details of this licence are available at: https://creativecommons.org/licenses/by-nc-nd/4.0/

\section{LICENCE}

CC BY-NC-ND 4.0

\section{REPOSITORY RECORD}

Santos, Jenifer, Goran T. Vladisavljevic, R.G. Holdich, Marijana M. Dragosavac, and Jose Munoz. 2015. "Controlled Production of Eco-friendly Emulsions Using Direct and Premix Membrane Emulsification". figshare. https://hdl.handle.net/2134/17475. 


\section{Graphical Abstract (for review)}

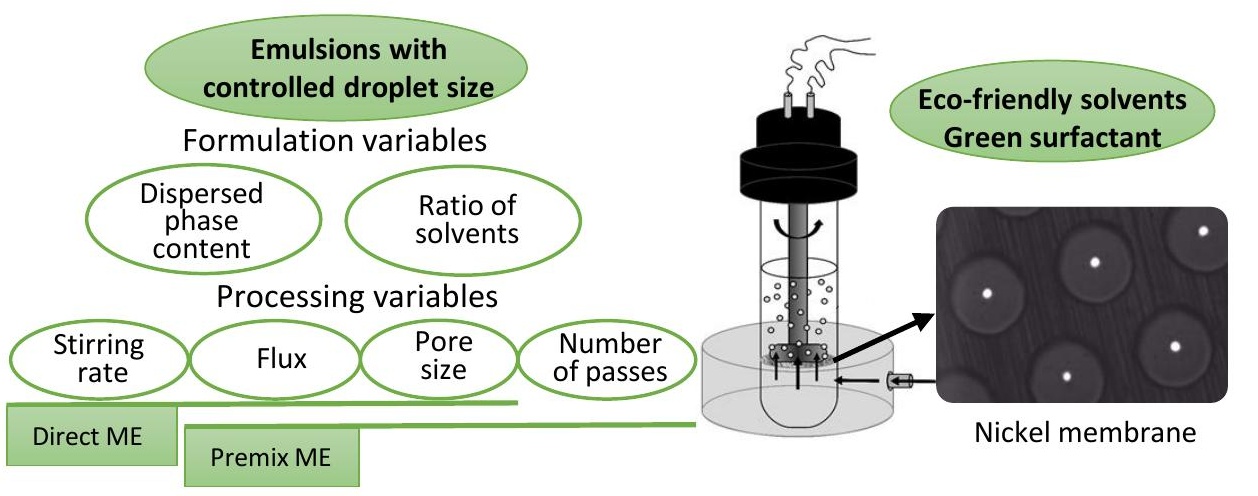




\section{Highlights}

- Production of size-controlled eco-friendly emulsions was achieved with ME.

- The most uniform emulsion was obtained with pure d-limonene.

- The addition of AMD-10 caused a decrease in droplet size at the same energy input.

- Droplet size lower than the pore size was obtained in premix ME.

- Emulsion with a dispersed phase content of $40 \mathrm{wt} \%$ showed viscoelastic properties. 
1 Controlled production of eco-friendly emulsions using direct

2

3

4

5

$6{ }^{1}$ Reología Aplicada. Tecnología de Coloides. Departamento de Ingeniería Química.

7 Facultad de Química. Universidad de Sevilla c/ P. García González, 1, E41012, Sevilla

8 Spain.

$9{ }^{2}$ Chemical Engineering Department, Loughborough University, Loughborough, 10 Leicestershire LE11 3TU, UK.

11 *Corresponding author. Tel.: +44 (0)1509 222518. E-mail address:

12 G.Vladisavljevic@lboro.ac.uk

\section{Abstract}

15 Eco-friendly O/W emulsions were produced by membrane emulsification using nickel membrane consisting of hexagonal arrays of cylindrical pores of 10 or $20 \mu \mathrm{m}$ diameter and $200 \mu \mathrm{m}$ spacing. The dispersed phase was a mixture of $\mathrm{N}, \mathrm{N}$-dimethyldecanamide $\left(\mathrm{AMD}-10^{\mathrm{TM}}\right)$ and $\mathrm{d}$-limonene containing $0-35 \mathrm{wt} \% \mathrm{AMD}-10^{\mathrm{TM}}$ in the dispersed phase and the continuous aqueous phase was $3 \mathrm{wt} \%$ polyoxyethylene glycerol fatty acid ester (Levenol ${ }^{\circledR}$ C-201). In direct membrane emulsification, the droplet-to-pore size ratio was 1.5-4.6 and the most uniform droplets were obtained with pure d-limonene at a stirrer speed of $620 \mathrm{rpm}$, corresponding to the peak shear stress on the membrane surface of $7 \mathrm{~Pa}$. In premix membrane emulsification, the median droplet diameter decreased with increasing the transmembrane flux and was smaller than the pore size 
25 at the flux above $2000 \mathrm{~L} \mathrm{~m}^{-2} \mathrm{~h}^{-1}$. The droplet size was $6 \mu \mathrm{m}$ after two passes through

26 the membrane with a pore diameter of either 10 or $20 \mu \mathrm{m}$. The viscosity of emulsions

27 with $30 \mathrm{wt} \%$ was not influenced by the shear rate but an emulsion with a dispersed 28 phase content of $40 \mathrm{wt} \%$ showed shear thinning behaviour and viscoelastic properties.

29 The produced emulsions can be used as environmentally friendly matrices for 30 incorporation of agrochemical actives.

32 Keywords: Membrane Emulsification, Stirred Cell, Eco-Friendly Emulsions, Green 33 Solvents, Agrochemicals, Emulsion Rheology.

\section{Introduction}

36 The task of product engineering is to design products of desirable features for given 37 applications. All properties are the result of certain physical and chemical characteristics of the product, which are determined by the choice of the formulation

39 and processing conditions. Many important properties of emulsions are largely 40 determined by structural parameters such as volume ratio of the phases, particle size 41 distribution and mean particle size (Schubert et al., 2003). Production of emulsion-

42 based systems with specific physicochemical and functional properties often requires 43 control over the particle size distribution (PSD) (McClements, 2005, Santos et al., 44 2011).

45 Conventional emulsification devices such as colloid mills, rotor-stator mixers, high46 pressure homogenizers and ultrasonic homogenizers offer limited flexibility in terms of 47 PSD. Recently, membrane emulsification (ME) has received much attention due to its 
48 ability to control the mean droplet size over a wide range together with the ability to

49 provide a narrow size distribution (Kosvintsev et al., 2005). Low energy consumption

50 lies at the heart of sustainable and socially responsible society (Cussler and Moggridge,

51 2011). The reduction in energy requirements by using ME is very significant when

52 compared with other homogenization processes. In fact, energy densities required to

53 achieve a mean droplet size of $1-10 \mu \mathrm{m}$ using premix ME typically range from $10^{4}$ to

$5410^{6} \mathrm{Jm}^{-3}$, while those of rotor-stator devices and high pressure homogenizers range

55 from $10^{6}$ to $10^{8} \mathrm{Jm}^{-3}$ (Karbstein and Schubert, 1995). In addition, the ability to form

56 uniform dispersions with a technique that can be scaled from small scale to industrial

57 production makes the process very attractive (Peng and Williams, 1998); cross flow

58 membrane emulsification being the technique of choice for scaling-up.

59 Two main types of ME processes have been developed: direct ME involving the permeation of pure dispersed phase through a microporous membrane into agitating

61 or recirculating continuous phase and premix ME involving the passage of previously 62 prepared coarse emulsion through the membrane (Charcosset et al., 2004). Premix ME provides several advantages over direct ME: (i) the dispersed phase flux is higher, so

64 the time required for the production is very short; (ii) the mean droplet-to-pore size ratios are smaller than in direct $\mathrm{ME}$. In direct $\mathrm{ME}$, the mean droplet-to-pore size ratio can range between 2 and 50 (Ma, 2003, Yuan et al., 2009, Zhou et al., 2009), but it is often below 10. In premix ME, the mean droplet-to-pore size ratio is typically between 0.6 and 2 (Vladisavljević et al., 2006); (iii) the process parameters are easier to control 69 than in direct ME. One of the disadvantages of premix ME is a higher emulsion polydispersity compared to direct ME. 
71 Premix ME has been applied using a wide range of membranes, such as Shirasu Porous

72 Glass (SPG) membrane (Suzuki et al., 1996), polycarbonate (Yafei et al., 2009), nylon

73 and nitrocellulose polymeric membranes (Ramakrishnan et al., 2012), and nickel

74 microsieves with rectangular and square membranes (Nazir et al., 2011, 2013). Typical

75 laboratory devices for ME are SPG micro kits (Kukizaki and Goto, 2007) and Micropore

76 Dispersion Cell (MDC) (Kosvintsev et al., 2005). Although MDC has been widely used in

77 direct ME, so far there are no published studies on premix ME in MDC.

78 In recent years, there has been an increasing interest in using the so-called green

79 solvents due to the need to replace traditional petrochemical organic solvents by more

80 environmentally friendly solvents derived from agricultural crops (Anastas and

81 Wagner, 1998). N,N-dimethyldecanamide $\left(\mathrm{AMD}-10^{\mathrm{TM}}\right)$ is considered as a safe

82 biosolvent, according to the Environmental Protection Agency in 2005 and has

83 excellent solubilizing properties towards agrochemical actives. Therefore, AMD- $10^{\mathrm{TM}}$ is

84 a suitable solvent for agrochemical use (Hofer and Bigorra, 2007), that imposes

85 minimal risk to the farmers while satisfying the needs of customers, which is a principal

86 aim of the product design (Brokel et al., 2007).

87 D-limonene, a naturally occurring hydrocarbon, is a cyclic monoterpene, which is

88 commonly found in the rinds of citrus fruits such as grapefruit, lemon, lime, and in

89 particular, oranges. D-limonene exhibits good biodegradability, hence it may be used

90 as a direct substitute for toxic organic solvents (Walter, 2010, Medvedovici et al.,

91 2012). These two solvents can meet the ever-increasing performance, safety and

92 environmental demands of 21st century solvents. In this study, mixtures of d-limonene

93 and AMD-10 ${ }^{\mathrm{TM}}$ will be used as a dispersed phase. The use of these solvent blends as a 
94 dispersed phase instead of common organic solvents and vegetable oils could

95 represent a challenge for the size control in $\mathrm{ME}$, due to their distinct physical

96 properties, such as low viscosity, low interfacial tension and a medium solubility in

97 water of AMD-10 ${ }^{\mathrm{TM}}\left(340 \mathrm{mg} \mathrm{L}^{-1}\right)$.

98 In addition, environmentally friendly surfactants have also attracted significant interest

99 recently. Polyoxyethylene glycerol esters derived from cocoa oil are non-ionic

100 surfactants obtained from a renewable source, which fulfil the environmental and

101 toxicological requirements for eco-friendly foaming and/or emulsifying agents (Castán

102 and González, 2003). Their use as green surfactants in detergents and personal care

103 products is disclosed in several patents (Lutz, 2006; Denolle, 2011). Levenol ${ }^{\circledR}$ C-201

104 and Levenol ${ }^{\circledR} \mathrm{H} \& \mathrm{~B}$ are commercial polyoxyethylene glycerol esters. The former was

105 found to be more surface active at the biocompatible $\alpha$-pinene/water interface than

106 Levenol H\&B, its counterpart with a lower number of oxyethylene groups (Trujillo-

107 Cayado et al., 2014a and 2014b).

108 The main objective of this work was to produce O/W eco-friendly emulsions with a

109 controlled mean droplet size using ME. For the first time, premix ME has been

110 performed in a Micropore Dispersion Cell (MDS) using micro-engineered membranes

111 with circular pores. The operation procedure, formulation, pore size, and process

112 parameters were optimized in order to obtain finer emulsions with low energy inputs.

113 These emulsions may be used as matrices for incorporation of active agrochemical

114 ingredients. This study is a contribution towards the development of new emulsion

115 products, which may fulfil the customers' needs as well as the requirements of the

116 related industries. 


\section{Experimental}

\section{2.1. Materials}

120 N,N Dimethyl Decanamide (Agnique AMD-10 ${ }^{\mathrm{TM}}$ ) was kindly provided by BASF. D121 Limonene was supplied by Sigma Chemical Company. The dispersed phase was a 122 mixture of $A M D-10^{T M}$ and d-limonene containing 0,25 , or 35 wt\% of AMD-10 ${ }^{\mathrm{TM}}$. The 123 dispersed phase content in the prepared emulsions was $30 \mathrm{wt} \%$ in all experiments 124 except those reported in Figure 8, where it was 5-40 wt \%.

125 The continuous phase was 3 wt\% Levenol $^{\circledR}$ C-201 and 0.1 wt\% antifoam agent 126 dissolved in deionized water. Levenol ${ }^{\circledR}$ C-201 is a nonionic surfactant derived from 127 cocoa oil, received as a gift from KAO Chemicals. It is a trade name of glycereth-17 128 cocoate (HLB:13), which is an ester of coconut acid and a polyethylene glycol ether of 129 glycerol containing an average of 17 ethylene oxide units per molecule. RD antifoam emulsion (DOW CORNING ${ }^{\circledR}$ ) was used as antifoaming agent. This commercial product consists of an aqueous solution containing polydimethyl siloxane $(<10 \mathrm{wt} \%)$ and 132 dimethyl siloxane, hydroxyl-terminated (<10 wt\%).

\subsection{Membrane and membrane module}

134 The emulsions were obtained using a Micropore Dispersion Cell (MDS), a stirred cell 135 with a flat disc membrane under the paddle stirrer shown in Figure 1. Both stirred cell 136 and membranes were supplied by Micropore Technologies Ltd. (Loughborough, UK).

137 The agitator was driven by a 24 V DC motor (INSTEK Model PR 3060) and paddle 138 rotation speed was controlled by the applied voltage. 
139 The membranes used were nickel membranes containing uniform cylindrical pores

140 with a diameter of $d_{p}=10 \mu \mathrm{m}$ or $d_{p}=20 \mu \mathrm{m}$ and a spacing of $L=200 \mu \mathrm{m}$. The

141 membranes were fabricated by the LIGA process, which involves galvanic deposition of

142 nickel onto a template formed by photolithography and etching. Perfectly ordered

143 hexagonal arrays of pores with one pore at the centre of each hexagonal cell can be 144 seen on the micrographs in Figure 2.

145 The porosity of a membrane with regular hexagonal pore array is given by:

$$
\varepsilon=\frac{\pi}{2 \sqrt{3}}\left(\frac{d_{p}}{L}\right)^{2}
$$

147 For the membranes used in this work, the porosity calculated from Eq. (1) is $0.26 \%$ and $1480.90 \%$ for $d_{p}=10$ and $20 \mu \mathrm{m}$, respectively. The effective cross-sectional area of the 149 whole membrane is $8.5 \mathrm{~cm}^{2}$, which is significantly greater than $1.4 \mathrm{~cm}^{2}$, which was the 150 membrane area used in previous premix ME studies with microsieve membranes 151 (Nazir et al., 2011, 2013).

\section{2.3. Emulsion production}

\section{2.3.1. Direct membrane emulsification}

154 Dispersed phase was injected through the membrane using a syringe pump (Secondary 155 Dual Pump, World Precision Instruments, Sarasota, Florida) at the constant flow rate of $156110-910 \mathrm{~mL} \mathrm{~h}^{-1}$, corresponding to the dispersed phase flux of 129-1070 $\mathrm{L} \mathrm{m}^{-2} \mathrm{~h}^{-1}$ (See 157 Figure 1A). The stirring speed was fixed at 400-1200 rpm. Once the desired amount of 158 oil had passed though the membrane, both the pump and the agitator were switched 159 off and the droplets were collected and analyzed. The membrane was cleaned with 4 
$160 \mathrm{M} \mathrm{NaOH}$ in an ultrasonic bath for $5 \mathrm{~min}$ followed by treatment in $2 \mathrm{wt} \%$ citric acid for 5 $161 \min$.

\section{$162 \quad$ 2.3.2. Premix membrane emulsification}

163 The mixture of solvents and the continuous phase was first premixed for one minute 164 using a magnetic bar to produce a coarse emulsion with large droplets. This coarse 165 emulsion was then injected 1-3 times through the membrane using a syringe pump 166 (Model 11 Plus, Harvard Apparatus) at the constant flow rate of $110-910 \mathrm{~mL} \mathrm{~h}^{-1}$, 167 corresponding to the flux of $129-1070 \mathrm{~L} \mathrm{~m}^{-2} \mathrm{~h}^{-1}$ (See figure 1B). The membrane was not 168 cleaned between the passes. The emulsion samples obtained after each pass were 169 collected and analysed.

\section{2.4. Droplet size distribution measurements}

171 PSD of oil droplets was determined by static laser light scattering (laser diffraction) 172 using Mastersizer 2000 (Malvern, Worcestershire, United Kingdom). All measurements 173 were repeated three times for each sample.

174 The mean droplet diameter was expressed as the volume median diameter $\mathrm{d}(\mathrm{v}, 0.5)$, 175 which is the diameter corresponding to 50 vol\% on the cumulative distribution curve.

176 The relative span of a drop size distribution was used to express the degree of drop 177 size uniformity (see Eq. 2).

$$
\operatorname{span}=\frac{[d(v, 0.9)-d(v, 0.1)]}{d(v, 0.5)}
$$

\subsection{Rheological measurements}


180 Rheological experiments were conducted with AR 1000 controlled-stress rheometer

181 (TA instruments, USA), equipped with a cone-plate of $60 \mathrm{~mm}$ diameter and 1 degree.

182 Flow curves were generated from $0.05 \mathrm{~Pa}$ to $1 \mathrm{~Pa}$ at $20^{\circ} \mathrm{C}$. Small amplitude oscillatory

183 shear tests were carried out for the emulsion containing $40 \mathrm{wt} \%$ of dispersed phase.

184 The frequency sweep was carried out in the 20-0.5 rad s $\mathrm{s}^{-1}$ angular frequency range at 185 shear stress amplitude of $0.05 \mathrm{~Pa}$. This was previously determined by conducting 186 oscillatory stress sweeps at three different frequencies, namely $0.63 \mathrm{rad} \mathrm{s}^{-1}, 6.3 \mathrm{rad} \mathrm{s}^{-}$ $187{ }^{1}$ and $18.9 \mathrm{rad} \mathrm{s}^{-1}$. All measurements were repeated 3 times with each emulsion. 188 Sampling from the top part of the container in contact with air was avoided.

\section{3. Results}

\subsection{Reproducibility of experimental data}

Figure 3 shows PSD curves for the emulsions prepared using direct ME with $10 \mu \mathrm{m}$ membrane (Fig. 3A) and premix ME with $20 \mu \mathrm{m}$ membrane (Fig. 3B). In each case, the dispersed phase contained $25 \mathrm{wt} \% \mathrm{AMD}-10^{\mathrm{TM}}$ and $75 \mathrm{wt} \%$ d-limonene. Replicated runs

1,2 and 3 in Fig. $3 A$ were performed on the same day, while run 4 was done in two days, after several other experiments had been performed in the meantime. PSD for all replicates was very similar, which indicates that the membrane cleaning procedure was robust and successful. The average $D(v, 0.5)$ value was $(28.79 \pm 1.37) \mu \mathrm{m}$ and span was $1.35 \pm 0.03$, where the error margins were calculated as one standard deviation away from the mean. There is no difference between a new and used membrane provided that a new membrane was treated with a wetting agent to render the surface hydrophilic (Fig. 3A). The new membrane that was not treated with wetting agent exhibited the broadest particle size distribution in Fig. 3A. 
203 In addition, PSD for the emulsions prepared by premix ME did not change substantially

204 in the experiments repeated 3 times under constant experimental conditions (Fig 3B).

205 The average $D(v, 0.5)$ value was $(23.16 \pm 1.85) \mu \mathrm{m}$ and span was $1.78 \pm 0.09$. The

206 reproducibility of the results in direct ME was better than that in the premix process,

207 probably because the PSD of the coarse emulsion was not exactly the same in all

208 premix ME runs. In both processes, bimodal distributions were obtained and PSD was

209 more uniform in the samples prepared by direct ME.

\section{$210 \quad 3.2$ Laser diffraction measurements}

\section{3.2.1. Direct Membrane Emulsification}

212 Figure 4 shows PSD for the emulsions prepared by direct ME at $620 \mathrm{rpm}$ and $600 \mathrm{~L} \mathrm{~m}^{-2}$

$213 \mathrm{~h}^{-1}$ with a $10 \mu \mathrm{m}$ and $20 \mu \mathrm{m}$ membrane as a function of the solvent ratio in the 214 dispersed phase. An increase in the content of $A M D-10^{T M}$ in the dispersed phase 215 caused a shift of the distribution towards smaller droplet sizes and the distribution 216 became wider, as evidenced by higher span values (Table 1). This could be due to the 217 low interfacial tension of the solvent blends compared to pure d-limonene (Table 2). 218 The interfacial tension force is the main force resisting the drag force and holding a 219 growing droplet at the membrane surface. By decreasing the interfacial tension, the 220 droplets detach sooner from the membrane surface and the resultant droplet size is 221 smaller. In addition, AMD-10 $10^{\mathrm{TM}}$ is more polar solvent than d-limonene (the solubility of $222 \mathrm{AMD}-10^{\mathrm{TM}}$ and D-Limonene in water is 340 and $13.8 \mathrm{mg} \mathrm{L}^{-1}$, respectively), which means 223 that the solvent blends have a higher affinity towards the hydrophilic membrane 224 surface than pure d-limonene. The PSD curves for pure limonene are monomodal, 225 suggesting that the membrane was not wetted by pure d-limonene during 
emulsification. In addition, the impact of the pore size on the mean droplet size was

227 very substantial for the pure limonene emulsions and negligible for the 25/75

228 emulsions. This may be related to the low interfacial tension of the mixture that is the

229 crucial property to achieve low droplet size (Santos et al., 2014). The subsequent

230 experiments will be done using the $25 / 75$ solvent mixture which is a compromise

231 between a need to obtain a narrow distribution and to replace as much d-limonene as

232 possible by a cheaper $\mathrm{AMD}-10^{\mathrm{TM}}$ solvent.

233 Figure 5 shows the effect of stirring speed on the droplet size distribution for $25 / 75$

234 emulsions prepared with a $10 \mu \mathrm{m}$ membrane at the oil flux of $600 \mathrm{~L} \mathrm{~m}^{-2} \mathrm{~h}^{-1}$. The

235 increase of stirring speed caused the PSD curves to shift toward smaller droplet sizes.

236 In addition, the volume median diameter decreased with increasing the stirring speed

237 (Fig. 6), which was due to an increase of the drag force acting on the droplets. The

238 same stirring rate vs. droplet size relationship was reported by Kosvintsev et al. (2005)

239 and Stillwell et al. (2007) for sunflower O/W emulsions. The droplet size showed large

240 variations with stirring speed up to $620 \mathrm{rpm}$, corresponding to average shear stress at

241 the membrane surface of 6.25 Pa. However, the effect was less pronounced at the

242 higher stirring speeds, when the volume median diameter virtually reached its

243 asymptotic value. Figure 6 also provides a comparison of experimental drop size and

244 model prediction at different stirring speeds. The shear-capillary model used in this

245 work (see Appendix A) does not recognise the dispersed phase flux as having a

246 contribution to the formed droplet size. Therefore, the model should represent the

247 smallest droplet size that can be produced for a given set of operating conditions. It

248 could explain why the model fits the experimental data best at high stirring speeds, 
where the droplet formation times are very short due to high drag forces exerted on

250 the droplets by the stirrer (Dragosavac et al., 2008).

251 Figure 6 also shows the influence of stirring speed on the span values for the emulsions 252 prepared at $600 \mathrm{~L} \mathrm{~m}^{-2} \mathrm{~h}^{-1}$ with a $10 \mu \mathrm{m}$ membrane. The higher span values obtained 253 above $620 \mathrm{rpm}$ could be attributed to more significant deformation of the droplets on 254 the membrane surface before detachment due to high shearing, which can lead to 255 more pronounced droplet interactions with the membrane surface and membrane 256 wetting. The optimal rotational speed with regard to droplet size uniformity was 620 $257 \mathrm{rpm}$, which corresponded to the peak shear stress on the membrane surface of $7 \mathrm{~Pa}$.

258 Figure 7 shows $D(v, 0.5)$ and span as a function of transmembrane flux for the 259 emulsions prepared with a 10 and $20 \mu \mathrm{m}$ membrane. The rotational speed was kept at 260 the optimal value of $620 \mathrm{rpm}$. For both pore sizes, an increase in the transmembrane 261 flux led to an increase in the mean droplet size, while span did not show significant 262 variations. As the transmembrane flux is increased, the drop grows faster and the 263 interface cannot be stabilised fast enough by adsorbed emulsifier molecules. In 264 addition, at higher transmembrane fluxes a higher amount of oil will flow into the 265 growing drop during pinch off. This effect was more significant up to $400 \mathrm{~L} \mathrm{~h}^{-1} \mathrm{~m}^{-2}$ and 266 then the droplet size tended to stabilize, probably due to droplet-droplet interactions 267 on the membrane surface that restricted further droplet growth (Egidi et al., 2008).

268 The influence of pore size on $D(v, 0.5)$ was insignificant for the emulsions containing 269 AMD-10 $0^{\mathrm{TM}}$ in the dispersed phase. However, span increased with an increase in the 270 pore size. Therefore, the optimum conditions for direct ME in this work were: a pore 271 size of $10 \mu \mathrm{m}$, a transmembrane flux of $129 \mathrm{~L} \mathrm{~m}^{-2} \mathrm{~h}^{-1}$ and a stirrer speed of $620 \mathrm{rpm}$. 
272 Figure 8 shows the effect of dispersed phase content on $D(v, 0.5)$ for $25 / 75$ emulsions

273 prepared by direct ME at $129 \mathrm{~L} \mathrm{~m}^{-2} \mathrm{~h}^{-1}$ and $620 \mathrm{rpm}$ using a $10 \mu \mathrm{m}$ membrane. The

274 surfactant/oil ratio was kept at $0.10(\mathrm{w} / \mathrm{w})$ in all samples. The volume median diameter

275 decreased with increasing the dispersed phase content in the emulsion. For a given

276 surfactant/oil ratio $(R=0.10)$, when the dispersed phase content is increased, the

277 surfactant concentration in the continuous phase also increases, leading to the higher

278 viscosity of the continuous phase, $\eta_{c}$. It has been reported that the viscosity of the

279 continuous phase significantly affects the droplet size obtained in rotor stator

280 homogenizers and in direct ME. It is stated that an increase in $\eta_{c}$ will lead to an

281 increase of the drag force acting on the forming droplets at the same stirring speed

282 producing smaller droplets (Vankova et al., 2007, Dragosavac et al., 2008).

$283 \quad 3.2 .2$. Premix membrane emulsification

284 Figure 9A illustrates the effect of transmembrane flux on the PSD of emulsions

285 produced by premix ME with a $10 \mu \mathrm{m}$ membrane. Injection of pre-mix through the 286 membrane led to reduction in the droplet size and modification of the PSD compared 287 to that of the pre-mix.

288 An increase in the transmembrane flux caused a shift of the PSD curves towards lower

289 droplet sizes. As a result of energy input brought by fluid flow, large oil drops in the 290 coarse emulsion were deformed in the pores and broken up into smaller droplets (Van 291 Aken, 2002). A reduction in drop size occurred as a result of various disruptive forces, 292 such as shear and extensional forces, interfacial tension effects (Rayleigh and Laplace 293 instabilities) and impact forces due to droplet-droplet and droplet-pore wall 294 interactions (Vladisavljević et al., 2004 and 2006, Cheetangdee et al., 2011). Here, 
droplet-pore wall interactions are probably less significant than in SPG membrane, due to shorter pore lengths as a result of non-tortuous and non-interconnected pores and 297 small membrane thickness. The wall shear stress $\tau_{p}$ in cylindrical non-tortuous pores 298 with a diameter of $d_{p}$ is given by (Vladisavljević et al., 2006b): $\tau_{p}=8 \eta_{c} J /\left(\varepsilon d_{p}\right)$, where $299 \varepsilon$ is the membrane porosity defined by Eq. (1) and $J$ is the transmembrane flux. Hence, $300 \tau_{p}$ increases with increasing $J$, which results in more intensive droplet break-up, as 301 shown in Figs. 9 and 10. The droplet size can also be reduced by increasing number of passes through membrane, as shown in Figure 9B, due to additional amount of energy added to the system (Vladisavljević et al., 2006). The same trend was observed in this work, although larger droplets were still present in the product emulsion after two passes (Fig. 9B), probably due to partial droplet re-coalescence. Due to bimodal PSDs, the span values were 1.5-6 (the data not shown here). The fraction of larger droplets $(\mathrm{d}>10 \mu \mathrm{m})$ can be reduced by implementing three passes, as can be seen from the PSD curves at $706 \mathrm{~L} \mathrm{~m}^{-2} \mathrm{~h}^{-1}$ in Fig. $9 \mathrm{~B}$.

Figure 10 shows the effect of transmembrane flux on the volume median diameter of 310 the product emulsions after 1-3 membrane passes. The transmembrane pressure, $\Delta p$ 311 is equivalent to energy input per unit volume, $E_{V}$ and can be expressed as follows: $312 E_{V}=\Delta p=J\left(R_{m}+R_{f}\right)$, where $R_{m}$ and $R_{f}$ is the hydraulic resistance of the clean membrane and fouling layer, respectively. The fouling resistance occurs due to 314 accumulation of oil drops on the upstream side of the membrane (external fouling) 315 and inside the pores (internal fouling) (Vladisavljevic et al., 2004). The mean Sauter 316 diameter of an emulsion produced in mechanical emulsification device exponentially 317 decreases with increasing energy input per unit volume (Karbstein and Schubert, 
318 1995): $D_{3,2}=C E_{V}^{-b}$, where $C$ and $b$ are constants whose values depend on the

319 physical properties of the phases. If the total hydraulic resistance is constant, the 320 above equation can be simplified to $D_{3,2} \propto J^{-b}$. Therefore, the higher the flux, the 321 lower the resultant droplet size, which agrees with the results in Fig. 10. The same 322 behaviour was observed by Suzuki et al. (1996 and 1998) in premix ME with SPG and 323 PTFE membranes.

$324 D(v, 0.5)$ was less than $10 \mu m$ (the pore size) after two passes through the membrane 325 irrespective of the flux and even after a single pass at the flux of $2118 \mathrm{~L} \mathrm{~m}^{-2} \mathrm{~h}^{-1}$. Large 326 droplets of a pre-mix are squeezed as they pass through the pores due to elongational 327 forces. At high flux values, a deformed droplet remains elongated after it exits the 328 pore, due to high velocity of the continuous phase relative to that of the dispersed 329 phase (van der Zwan et al., 2006). The resulting long droplet filament is subjected to 330 Plateau-Rayleigh instability due to perturbations on its interface, which leads to jet 331 fragmentation into very fine droplets, typically smaller than the pore size. At low 332 fluxes, a squeezed droplet re-emerges on the downstream side of the membrane 333 acquiring a dumbbell shape. The droplet does not form a long cylinder, since the flow 334 rate of the continuous phase is insufficient and thus, Plateau-Rayleigh instability is not 335 relevant (van der Zwan et al., 2006). The droplet is disrupted due to Laplace instability 336 caused by the difference in capillary pressure between the dispersed phase in the neck 337 region inside the pore and the dispersed phase before and after the pore (in 338 hemispherical ends).

339 Figures $11(\mathrm{~A})$ and $(\mathrm{B})$ show the effect of transmembrane flux and number of passes 340 through the membrane, respectively, on the PSD for emulsions prepared using a 20 
$341 \mu \mathrm{m}$ membrane. As expected, the smallest droplets were obtained after two passes at

$3422118 \mathrm{~L} \mathrm{~m}^{-2} \mathrm{~h}^{-1}$ (due to the highest energy input) and the biggest droplets were 343 produced at $350 \mathrm{~L} \mathrm{~m}^{-2} \mathrm{~h}^{-1}$ after single pass.

344 Figure 12 shows the effect of transmembrane flux and number of passes on for the 20 $345 \mu \mathrm{m}$ pore size. The $\mathrm{D}(\mathrm{v}, 0.5)$ value after first pass at $2118 \mathrm{~L} \mathrm{~m}^{-2} \mathrm{~h}^{-1}$ was $15 \mu \mathrm{m}$ and was 346 higher than that for the $10 \mu \mathrm{m}$ pore size. At the constant flux, flow velocity in the 347 membrane pores is lower for larger pores, due to 3.5 times higher membrane porosity, 348 leading to less intensive droplet break-up. The volume median diameter after two 349 passes levelled off at about $6 \mu \mathrm{m}$ and was similar to the limiting $D(v, 0.5)$ value for the $35010 \mu \mathrm{m}$ pore size after two passes. However, span values for $20 \mu \mathrm{m}$ pore size 351 membrane were lower than those for the $10 \mu \mathrm{m}$ pore size (data not shown). 352 Therefore, in premix ME more uniform emulsion droplets were produced with the 353 higher pore size, as opposed to direct ME.

\section{3.3. Rheological measurements}

355 Figures $13 \mathrm{~A}$ and $13 \mathrm{~B}$ show flow properties of $30 \mathrm{wt} \%$ emulsions prepared by direct and 356 premix ME, respectively, as a function of transmembrane flux and number of passes. In 357 both cases, the pore size of the membrane was $10 \mu \mathrm{m}$. All samples with $30 \%$ dispersed 358 phase exhibited Newtonian behaviour with the flow curves fitting fairly well to the 359 Newtonian law. Hence, viscosities of these emulsions are not influenced by shear rate.

360 Increasing the stirring speed increases the viscosity of the samples, which supports 361 laser diffraction results. An increase of transmembrane flux and number of passes led 362 to an increase of viscosity. In addition, the emulsions prepared by premix ME showed 363 higher viscosities than the ones obtained by direct process. These results are in good 
correlation with the mean droplet diameters observed by laser diffraction. Clearly, emulsions with a dispersed phase content of $30 \mathrm{wt} \%$ did not possess enough internal structure to show shear thinning behaviour or viscoelastic properties.

By contrast, an emulsion with a dispersed phase content of $40 \mathrm{wt} \%$ exhibited shear thinning behaviour and viscoelastic properties. Measurable viscoelastic responses could not be obtained below $40 \mathrm{wt} \%$ dispersed phase. Figure $13 \mathrm{C}$ shows mechanical spectrum of a $40 \mathrm{wt} \%$ emulsion produced by direct ME at $620 \mathrm{rpm}$ and $129 \mathrm{~L} \mathrm{~m}^{-2} \mathrm{~h}^{-1}$. The loss modulus $G^{\prime \prime}$ was higher than the storage modulus $G^{\prime}$ at every frequency. This behaviour is typical in viscoelastic liquids ( $\tan \delta>1$ ) (Mezger, 2006). Emulsions with viscoelastic properties usually show better stabilities against creaming than the nonviscoelastic emulsions (Barnes, 1994).

\section{Conclusions}

The production of eco-friendly emulsions with a median droplet diameter ranging from 21 to $69 \mu \mathrm{m}$ has been demonstrated using direct and premix membrane emulsification $(\mathrm{ME})$ in a simple paddle-bladed stirred cell. An increase of the content of AMD-10 $0^{\mathrm{TM}}$ solvent in the dispersed phase caused a decrease in the mean droplet size and deterioration of the droplet size distribution, probably due to lower interfacial tension and higher polarity of the solvent blend compared to pure d-limonene. In direct ME, the mean droplet size decreased with increasing the stirring speed and decreasing the transmembrane flux. The droplet-to-pore size ratio was $2.2-4.6$ and $1.5-3.5$ for the membrane with a pore size of 10 and $20 \mu \mathrm{m}$, respectively. The minimum droplet-topore size ratio of 1.5 was smaller than 3 reported in direct ME with SPG membrane, 
probably due to very low interfacial tension of $1 \mathrm{mN} / \mathrm{m}$ when 25/75 solvent mixture

was used. The most uniform droplets were obtained at the flux of $600 \mathrm{~L} \mathrm{~m}^{-2} \mathrm{~h}^{-1}$ and the stirrer speed of $620 \mathrm{rpm}$, which corresponded to the peak shear stress on the membrane surface of $7 \mathrm{~Pa}$. For a constant surfactant/oil ratio $(R)$ of 0.10 , the mean droplet size decreased with increasing the dispersed phase content in the emulsion.

In premix $\mathrm{ME}$, the mean droplet size exponentially decreased with increasing transmembrane flux from an initial value greater than $50 \mu \mathrm{m}$ in a pre-mix to a final

394 value lower than the pore size in the emulsions processed at the flux above $2000 \mathrm{~L} \mathrm{~m}^{-2}$

$395 \mathrm{~h}^{-1}$. The mean droplet size was additionally reduced using two or three passes through 396 the membrane, but the particle size distribution was relatively broad. A lower 397 transmembrane flux and smaller number of passes were needed to achieve the same 398 droplet size reduction as with SPG membrane of the same pore size, probably due to 399 smaller interfacial tension in this work. The effect of pore size on the mean droplet size 400 was more pronounced in premix than in direct ME. This work demonstrates that 401 premix ME with only two passes through nickel micro-engineered membrane enables to obtain $\mathrm{O} / \mathrm{W}$ emulsions with very small mean droplet sizes compared to the pore 403 size. The mean droplet size lower than $6 \mu \mathrm{m}$ was achieved using both 10 and $20 \mu \mathrm{m}$ 404 membrane, but more uniform droplets were obtained with a $20 \mu \mathrm{m}$ membrane.

405 O/W emulsions with a dispersed phase content of 40 wt\% showed viscoelastic 406 properties, due to structuration in the emulsion. On the other hand, O/W emulsions 407 with a dispersed phase content of 30 wt\% exhibited Newtonian behaviour with the 408 viscosity values in a good correlation with the mean droplet sizes. 
411 The financial support received (Project CTQ2011-27371) from the Spanish Ministerio

412 de Economía y Competitividad, the European Commission (FEDER Programme) and

413 from V Plan Propio Universidad de Sevilla is kindly acknowledged.

414 The authors are also grateful to BASF and KAO for providing materials for this research.

\section{Appendix A}

417 For predicting the drop size of the dispersed phase, a force-balance model (Dragosavac 418 et al., 2008) has been used here.

419 The shear stress $\tau$ at the membrane surface varies with the radial distance from the 420 stirrer axis, $r$, according to the equations (Nagata, 1975):

421

For $r<r_{\text {trans }}$

$$
\tau=0.825 \eta_{c} \omega r \frac{1}{\delta}
$$

422

For $r>r_{\text {trans }}$

$$
\tau=0.825 \eta_{c} \omega r_{\text {trans }}\left(\frac{r_{\text {trans }}}{r}\right)^{0.6} \frac{1}{\delta}
$$

423 where $r_{\text {trans }}$ is the transitional radius, i.e. the radial distance where the shear stress is 424 greatest:

$$
\mathrm{r}_{\text {trans }}=1.23 \frac{D}{2}\left(0.57+0.35 \frac{D}{T}\right)\left(\frac{b}{T}\right)^{0.036} n_{b}^{0.116} \frac{R e}{1000+1.43 R e}
$$

425 Here, $D$ is the stirrer diameter, $T$ is the cell diameter, $b$ is the blade height, and $n_{b}$ is the 426 number of impeller blades (Fig. 1A). The rotating Reynolds number is given by: $\operatorname{Re}=$ $\omega \rho_{c} D^{2} /\left(2 \pi \eta_{c}\right)$, where $\rho_{c}$ and $\eta_{c}$ is the continuous phase density and viscosity, 428 respectively, and $\omega$ is the angular velocity.

429 The boundary layer thickness, $\delta$, is defined by the equation (Landau and Lifshitz, 1959):

$$
\delta=\sqrt{\eta_{c} /\left(\rho_{c} \omega\right)}
$$


431 The local shear stresses on the membrane surface are plotted in Figure 14. The

432 maximum shear stress $\tau_{\max }$ is expressed by putting $r=r_{\text {trans }}$ in Eq. (3):

$$
\tau_{\max }=0.825 \eta_{c} \omega r_{\text {trans }} \frac{1}{\delta}
$$

433 The droplet diameter, $x$, can be predicted from a simple force balance on a droplet at 434 pinch-off: $F_{d}=F_{c a}$, where $F_{c a}$ and $F_{d}$ are the capillary and drag force, respectively 435 (Kosvintsev et al., 2005):

$$
\begin{aligned}
& F_{c a}=\pi d_{p} \gamma \\
& F_{d}=9 \pi \tau x \sqrt{-r_{p}^{2}+\left(\frac{x}{2}\right)^{2}}
\end{aligned}
$$

$436 r_{p}$ is the pore radius and $y$ is the interfacial tension. Solving Eqs. (8) and (9) for $x$ gives

437 the equation for the drop diameter (Kosvintsev et al., 2005 and Stillwell et al., 2007):

$$
x=\frac{\sqrt{18 \tau^{2} r_{p}^{2}+2 \sqrt{81 \tau^{4} r_{p}^{4}+4 r_{p}^{2} \tau^{2} \gamma^{2}}}}{3 \tau}
$$

438 Since the pressure on the surface of the membrane is lowest at $\tau=\tau_{\max }$, the majority of

439 the drops will be formed near the transitional radius and thus $\tau_{\max }$ from Eq. (7) will be 440 used instead of $\tau$ in Eq. (10).

\section{References}

442 Anastas, P. T., \& Warner, J. C. Green Chemistry: Theory and Practice, Oxford University 443 Press, New York, 1998.

444 Barnes, H. A. (1994). Rheology of emulsions-a review. Colloids and Surfaces A: 445 Physicochemical and Engineering Aspects, 91, 89-95.

446 Brokel, U., Meier, W., \& Wagner, G. Introduction. In: Brokel, U., Meier, W., \& Wagner, 447 G, editors. Product Design and Engineering. Vol. 1: Basics and Technologies. Weinheim: 448 Wiley-VCH, 2007:1-3. 
449 Castán, P., \& González, X. Skin properties of glycerine polyethoxylene esters. In:

450 Proceedings of 33th Annual Meeting of CED, Vol. 33. 2003:325-338.

451 Charcosset, C., Limayem, I., \& Fessi, H. (2004). The membrane emulsification process452 a review. Journal of chemical technology and biotechnology, 79(3), 209-218.

453 Cheetangdee, N., \& Fukada, K. (2012). Protein stabilized oil-in-water emulsions 454 modified by uniformity of size by premix membrane extrusion and their colloidal 455 stability. Colloids and Surfaces A: Physicochemical and Engineering Aspects, 403, 5445661.

457 Cussler, E.L., \& Moggridge, G.D. Chemical Product Design, 2nd ed. Cambridge, UK: 458 Cambridge University Press, 2011.

459 Denolle, Y., Seita, V., \& Delaire V. European Patents and Applications. EP 2368971 A1 $460 \quad 20110928,2011$.

461 Dos Santos, R. G., Bannwart, A. C., Briceno, M. I., \& Loh, W. (2011). Physico-chemical 462 properties of heavy crude oil-in-water emulsions stabilized by mixtures of ionic and 463 non-ionic ethoxylated nonylphenol surfactants and medium chain alcohols. Chemical 464 Engineering Research and Design, 89(7), 957-967.

465 Dragosavac, M. M., Sovilj, M. N., Kosvintsev, S. R., Holdich, R. G., \& Vladisavljević, G. T. 466 (2008). Controlled production of oil-in-water emulsions containing unrefined pumpkin 467 seed oil using stirred cell membrane emulsification. Journal of Membrane 468 Science, 322(1), 178-188.

469 Egidi, E., Gasparini, G., Holdich, R. G., Vladisavljević, G. T., \& Kosvintsev, S. R. (2008) 470 Membrane emulsification using membranes of regular pore spacing: Droplet size and 471 uniformity in the presence of surface shear. Journal of Membrane Science, 323(2), $472 \quad 414-420$

473 Höfer, R., \& Bigorra, J. (2007). Green chemistry-a sustainable solution for industrial 474 specialties applications. Green Chemistry, 9(3), 203-212.

475 Karbstein, H., \& Schubert, H. (1995). Developments in the continuous mechanical 476 production of oil-in-water macro-emulsions. Chemical Engineering and Processing, 477 34(3), 205-211.

478 Kosvintsev, S. R., Gasparini, G., Holdich, R. G., Cumming, I. W., \& Stillwell, M. T. (2005). 479 Liquid-liquid membrane dispersion in a stirred cell with and without controlled 480 shear. Industrial \& Engineering Chemistry Research, 44(24), 9323-9330.

481 Kukizaki, M., \& Goto, M. (2007). Preparation and evaluation of uniformly sized solid 482 lipid microcapsules using membrane emulsification. Colloids and Surfaces A: 483 Physicochemical and Engineering Aspects, 293(1-3), 87-94.

484 Landau, L. D., \& Lifshitz, E. M. (1959). Fluid mechanics, 1959. Course of Theoretical 485 Physics. 
Lutz, P.J. Ca. Patents Applications.CA 2537554 A1 20060822, 2006.

487 Ma, G. (2003). Control of polymer particle size using porous glass membrane 488 emulsification: A review. China Particuology, 1(3), 105-114.

489 McClements, D. J. Food Emulsions: Principles, Practice, and Techniques. Boca Raton: 490 CRC Press, 2005.

491 Medvedovici, A., Udrescu, S., \& David, V. (2013). Use of a green (bio) solvent492 limonene-as extractant and immiscible diluent for large volume injection in the 493 RPLC-tandem MS assay of statins and related metabolites in human 494 plasma. Biomedical Chromatography, 27(1), 48-57.

495 Mezger, T. G. (2006). The rheology handbook: for users of rotational and oscillatory 496 rheometers. Vincentz Network GmbH \& Co KG.

497 Nagata, S. (1975). Mixing: principles and applications (Vol. 44). Tokyo: Kodansha.

498 Nazir, A., Schroën, K., \& Boom, R. (2011). High-throughput premix membrane 499 emulsification using nickel sieves having straight-through pores. Journal of Membrane 500 Science, 383(1), 116-123.

501 Nazir, A., Schroën, K., \& Boom, R. (2013). The effect of pore geometry on premix 502 membrane emulsification using nickel sieves having uniform pores. Chemical 503 Engineering Science, 93, 173-180.

504 Peng, S. J., \& Williams, R. A. (1998). Controlled production of emulsions using a 505 crossflow membrane: Part I: Droplet formation from a single pore. Chemical 506 Engineering Research and Design, 76(8), 894-901.

507 Ramakrishnan, S., Ferrando, M., Aceña-Muñoz, L., De Lamo-Castellví, S., \& Güell, C. 508 (2013). Fish oil microcapsules from O/W emulsions produced by premix membrane 509 emulsification. Food and Bioprocess Technology, 6(11), 3088-3101.

510 Santos, J., Trujillo-Cayado, L. A., Calero, N., \& Muñoz, J. (2014). Physical 511 characterization of eco-friendly O/W emulsions developed through a strategy based on 512 product engineering principles. AIChE Journal. 60(7), 2644-2653.

513 Schubert, H., Ax, K., \& Behrend, O. (2003). Product engineering of dispersed 514 systems. Trends in Food Science \& Technology, 14(1), 9-16.

515 Stillwell, M. T., Holdich, R. G., Kosvintsev, S. R., Gasparini, G., \& Cumming, I. W. (2007). 516 Stirred cell membrane emulsification and factors influencing dispersion drop size and 517 uniformity. Industrial \& Engineering Chemistry Research, 46(3), 965-972.

518 Suzuki, K., Fujiki, I., \& Hagura, Y. (1998). Preparation of Corn Oil/Water and 519 Water/Corn Oil Emulsions Using PTFE Membranes. Food Science and Technology 520 International, Tokyo, 4(2), 164-167. 
521 Suzuki, K., Shuto, I., \& Hagura, Y. (1996). Characteristics of the Membrane

522 Emulsification Method Combined with Preliminary Emulsification for Preparing Corn

523 Oil-in-Water Emulsions. Food Science and Technology International, Tokyo, 2(1), 43-47.

524 Trujillo-Cayado, L. A., Ramírez, P., Pérez-Mosqueda, L. M., Alfaro, M. C., \& Muñoz, J.

525 (2014a). Surface and foaming properties of polyoxyethylene glycerol ester

526 surfactants. Colloids and Surfaces A: Physicochemical and Engineering Aspects, 458(1),

$527 \quad 195-202$.

528 Trujillo-Cayado, L. A., Ramírez, Ruiz, M., Alfaro, M. C., \& Muñoz, J. (2014b). Adsorption

529 at the biocompatible - pinene-water interface and emulsifying properties of two eco-

530 friendly surfactants. Colloids and Surfaces B: Biointerfaces, 122(1), 623-629

531 van Aken, G. A. (2002). Flow-induced coalescence in protein-stabilized highly

532 concentrated emulsions. Langmuir, 18(7), 2549-2556.

533 van der Zwan, E., Schroen, K., van Dijke, K., \& Boom, R. (2006). Visualization of droplet

534 break-up in pre-mix membrane emulsification using microfluidic devices. Colloids and

535 Surfaces A: Physicochemical and Engineering Aspects, 277(1-3), 223-229.

536 Vladisavljević, G. T., Shimizu, M., \& Nakashima, T. (2004). Preparation of monodisperse 537 multiple emulsions at high production rates by multi-stage premix membrane 538 emulsification. Journal of Membrane Science, 244(1), 97-106.

539 Vladisavljević, G. T., Surh, J., \& McClements, J. D. (2006). Effect of emulsifier type on 540 droplet disruption in repeated Shirasu porous glass membrane 541 homogenization. Langmuir, 22(10), 4526-4533.

542 Vladisavljević, G. T., Shimizu, M. \& Nakashima, T. (2006b). Production of multiple 543 emulsions for drug delivery systems by repeated SPG membrane homogenization: 544 Influence of mean pore size, interfacial tension and continuous phase viscosity. Journal 545 of Membrane Science, 284(1-2), 373-383.

546 Walter J. (2010). Metabolism of terpenoids in animal models and humans. In: Husnu 547 Can Baser K, Buchbauer, G., editors. Handbook of essential oils: Science, Technology 548 and Applications. Boca Raton: CRC Press, 209-232.

549 Yafei, W., Tao, Z., \& Gang, H. (2006). Structural evolution of polymer-stabilized double 550 emulsions. Langmuir, 22(1), 67-73.

551 Yuan, Q., Williams, R. A., \& Biggs, S. (2009). Surfactant selection for accurate size 552 control of microcapsules using membrane emulsification. Colloids and Surfaces A: 553 Physicochemical and Engineering Aspects, 347(1), 97-103.

554 Zhou, Q. Z., Ma, G. H., \& Su, Z. G. (2009). Effect of membrane parameters on the size 555 and uniformity in preparing agarose beads by premix membrane emulsification. 556 Journal of Membrane Science, 326(2), 694-700. 

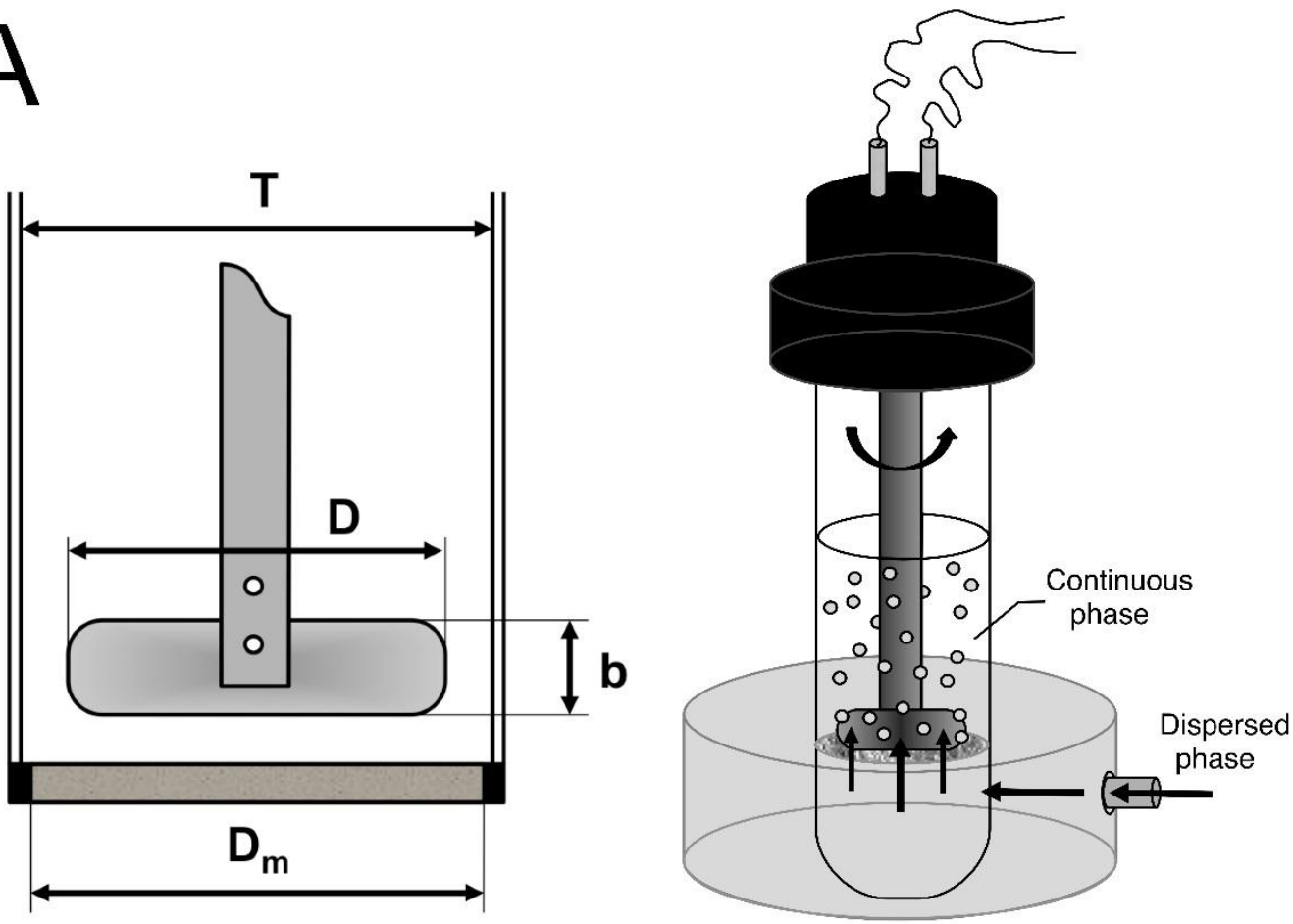

B
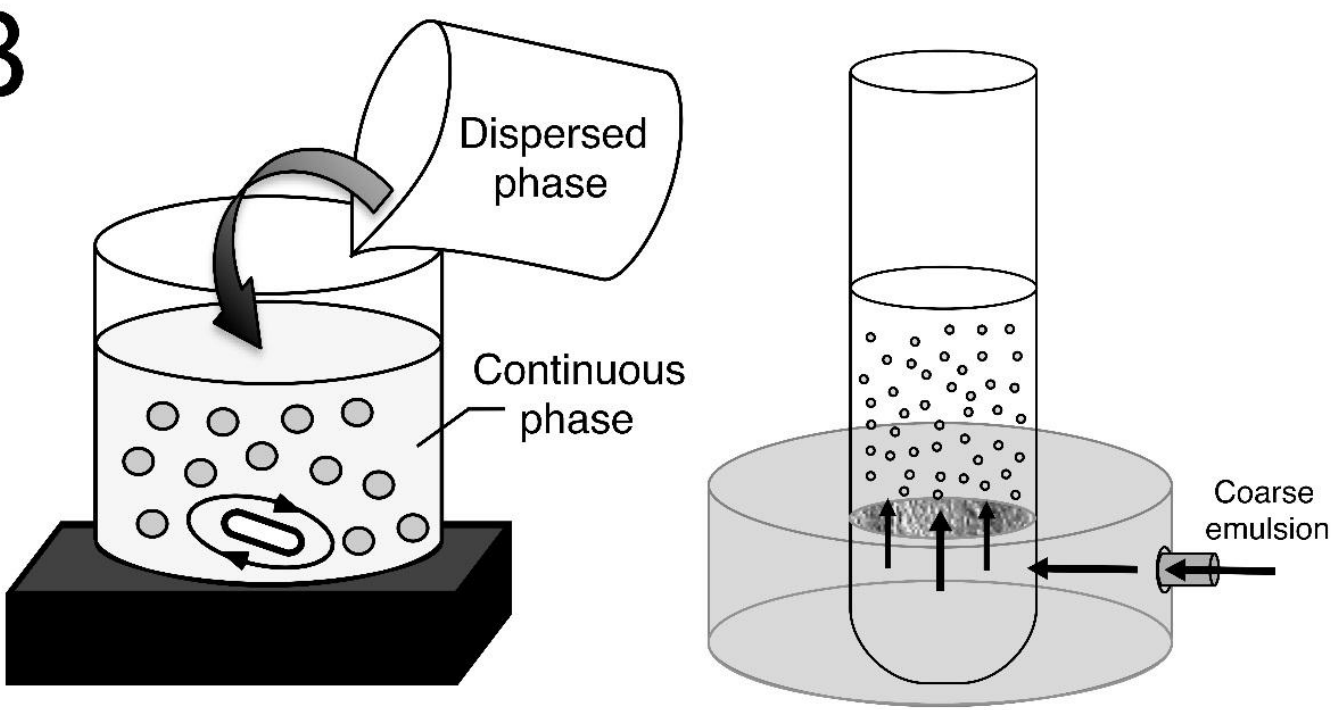

Figure 1. A) Schematic illustration of Dispersion Cell with simple paddle stirrer above a flat-disc membrane $\left(b=11 \mathrm{~mm}, D=30 \mathrm{~mm}, D_{m}=32 \mathrm{~mm}\right.$, and $T=37 \mathrm{~mm}$ ) used in direct ME. B) Schematic illustration of the premix ME process used. The coarse emulsion was prepared by magnetic stirrer and injected through the membrane without stirring. 
A)
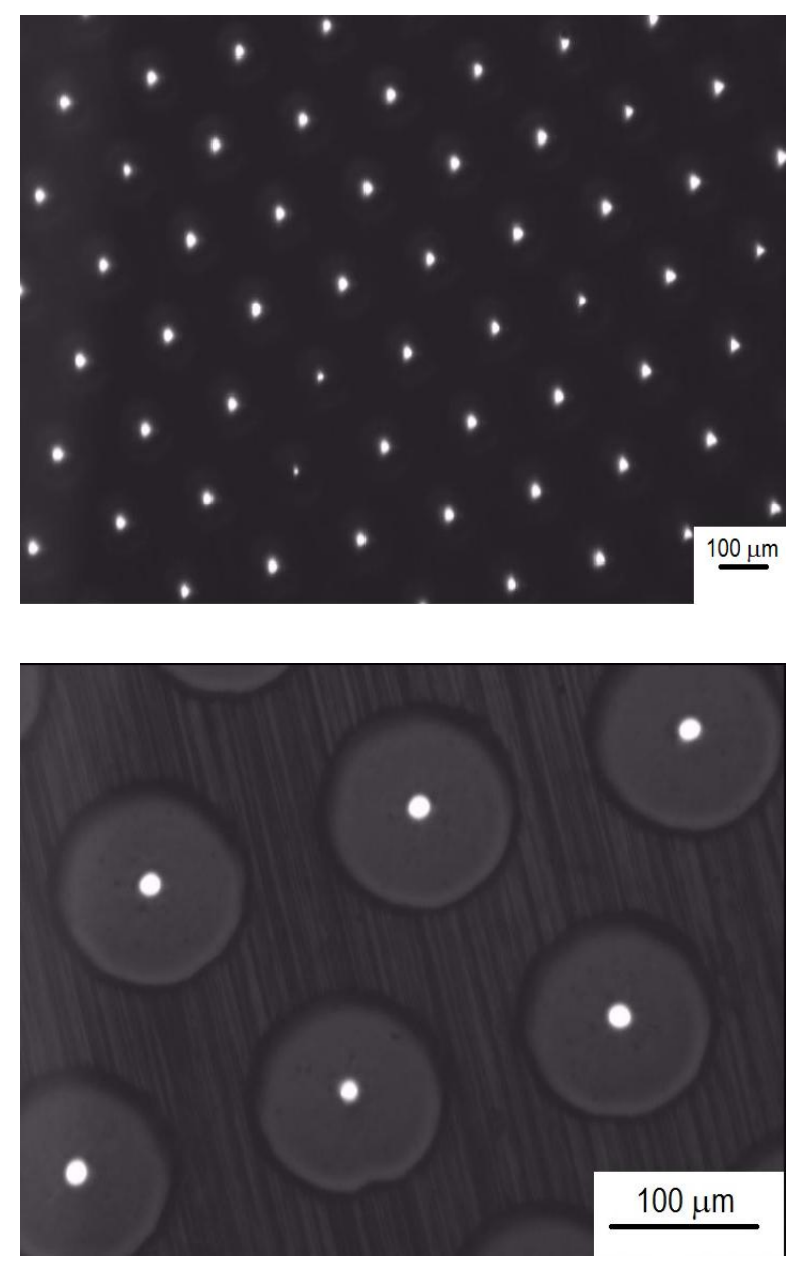

B)
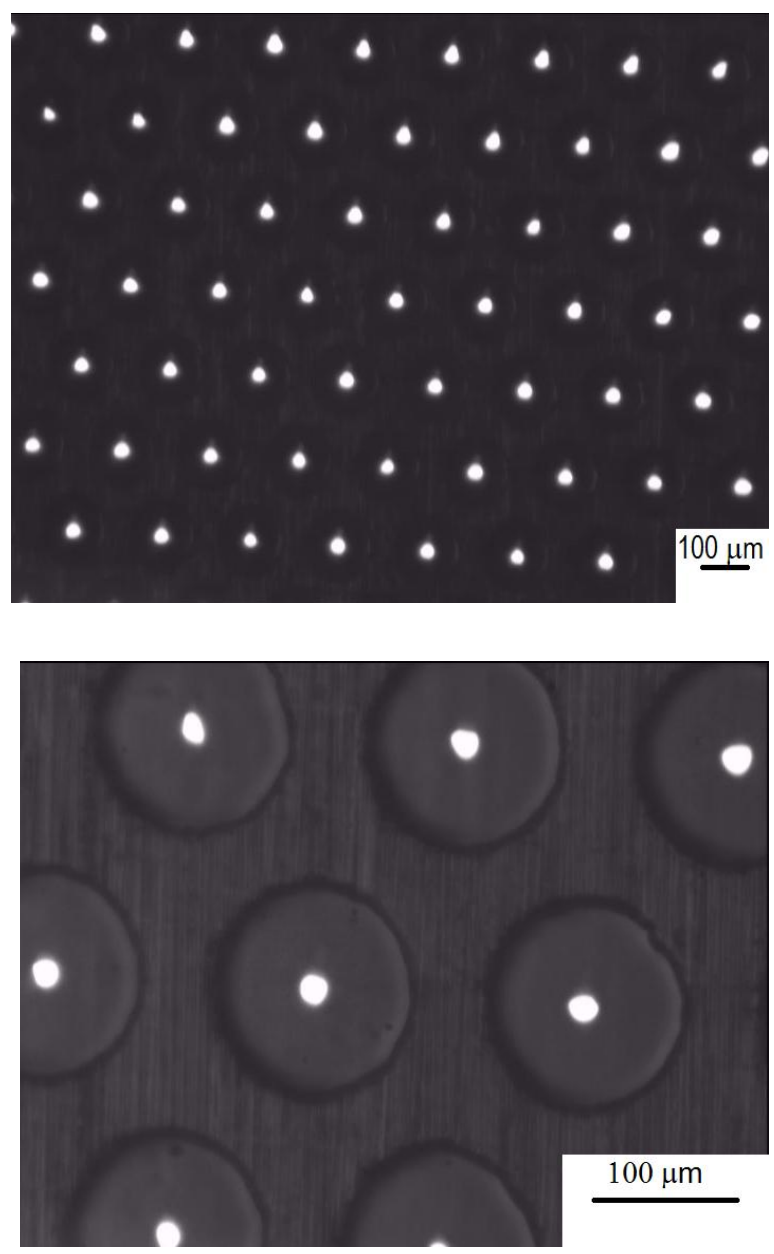

Figure 2. Photomicrographs of the membrane surface taken at two different magnifications: A) $10 \mu \mathrm{m}$ pore size membrane and B) $20 \mu \mathrm{m}$ pore size membrane. 
A)

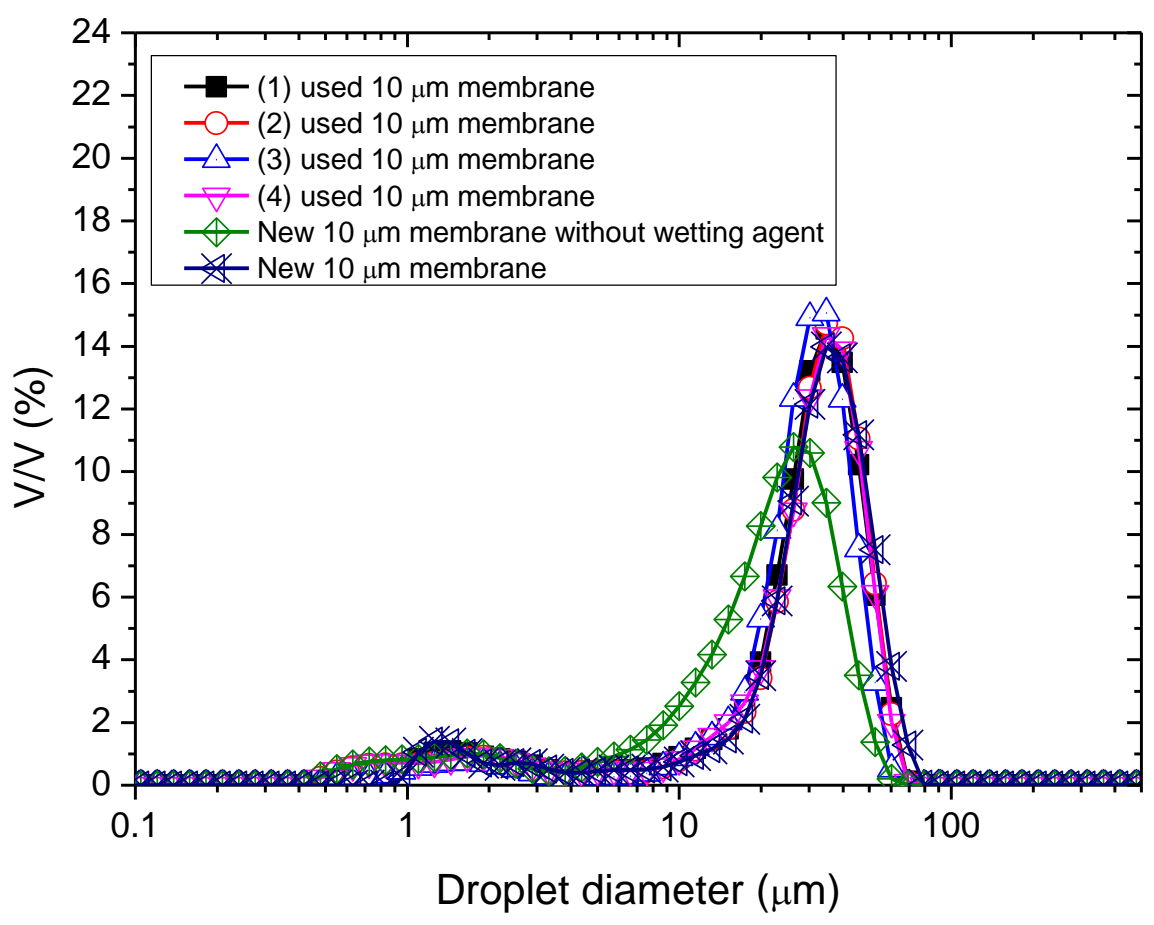

B)

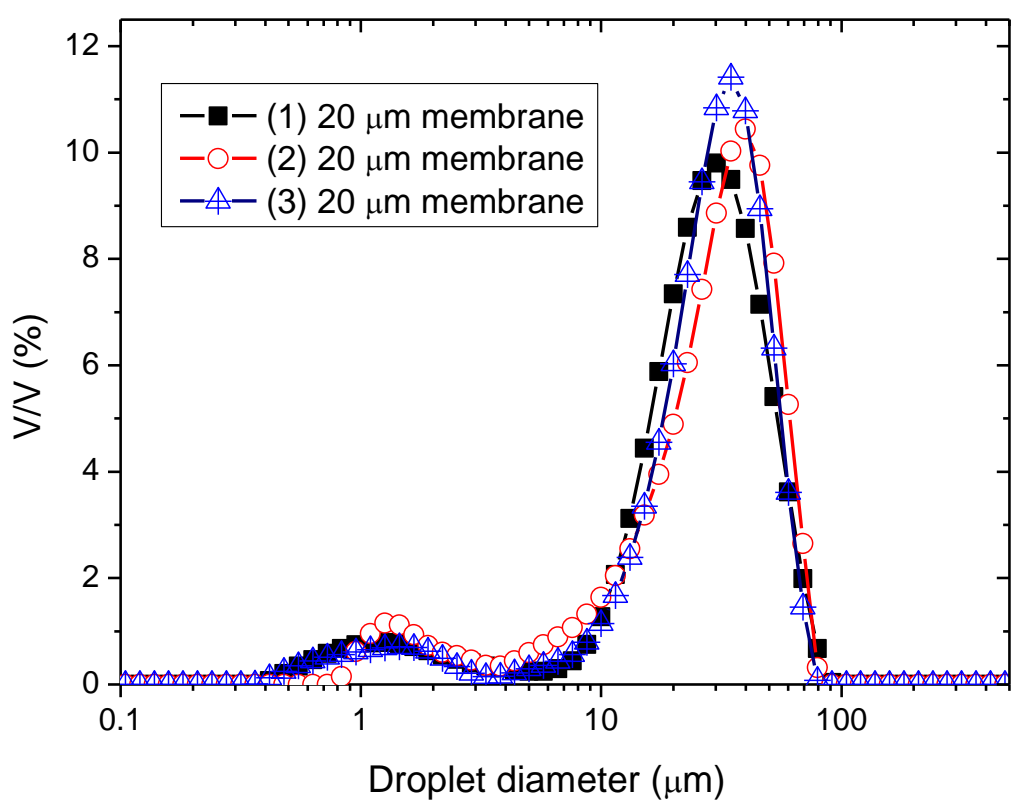

Figure 3. Particle size distribution of emulsions in repeated runs: A) 25/75 emulsion produced using direct ME at $850 \mathrm{rpm}$ and $600 \mathrm{~L} \mathrm{~m}^{-2} \mathrm{~h}^{-1}$ with a $10 \mu \mathrm{m}$ membrane and B) $25 / 75$ emulsion produced using single-pass premix ME at $706 \mathrm{~L} \mathrm{~m}^{-2} \mathrm{~h}^{-1}$ with a $20 \mu \mathrm{m}$ membrane. 


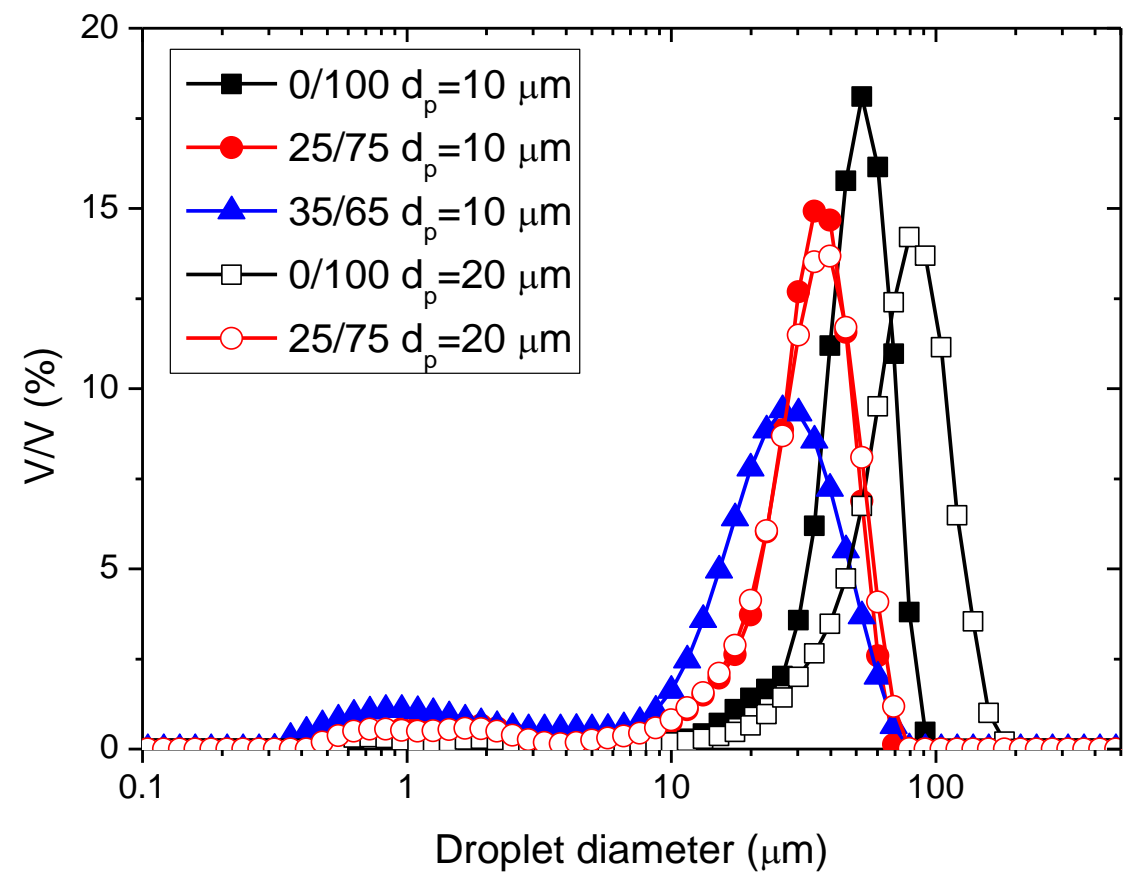

Figure 4. PSD for emulsions prepared by direct ME at $620 \mathrm{rpm}$ and $600 \mathrm{~L} \mathrm{~m}^{-2} \mathrm{~h}^{-1}$ as a function of the pore size of the membrane and the ratio of solvents in the dispersed phase. 
Figure 5

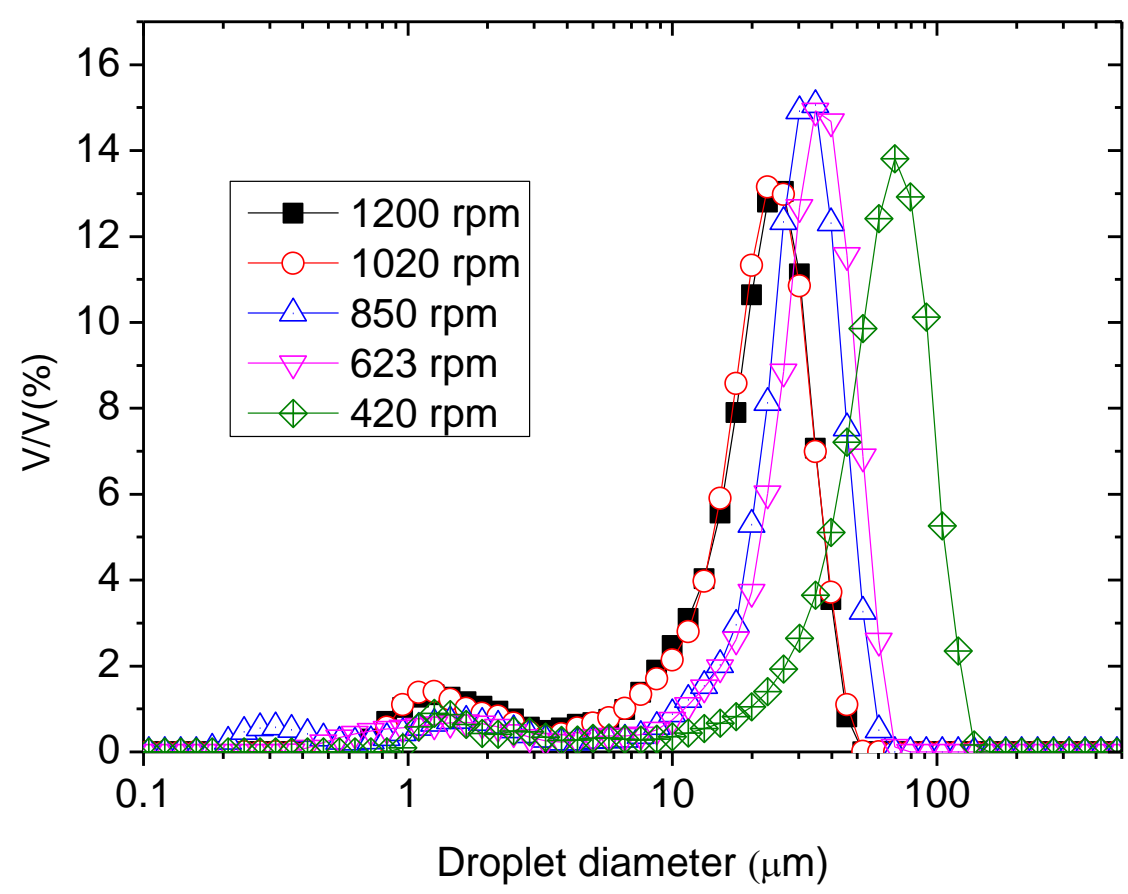

Figure 5. The effect of stirring speed on the PSD of 25/75 emulsions prepared by direct ME at $600 \mathrm{~L} \mathrm{~m}^{-2} \mathrm{~h}^{-1}$ with a $10 \mu \mathrm{m}$ membrane. 

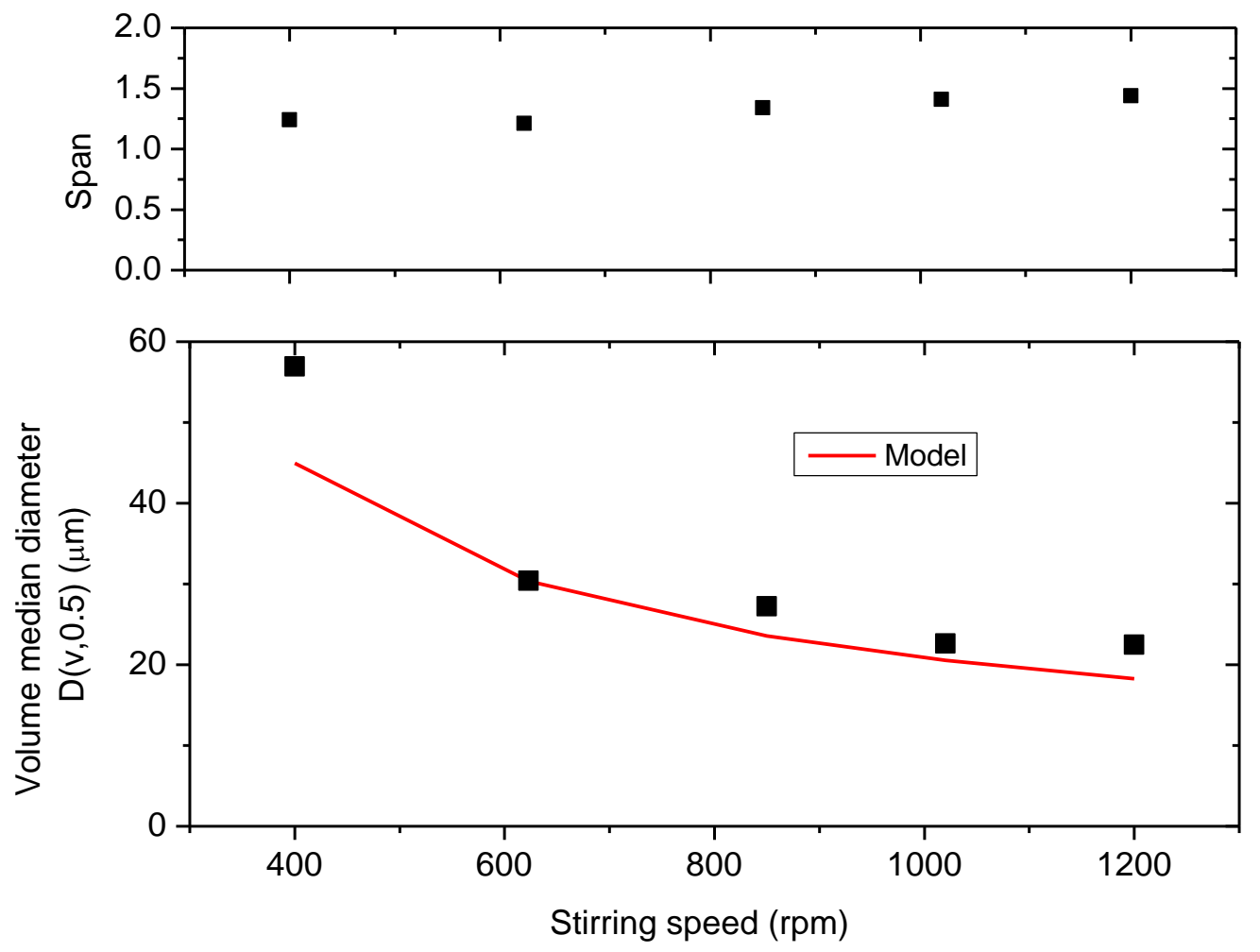

Figure 6. The volume median diameter, $D(v, 0.5)$ and span of the emulsions prepared by direct $\mathrm{ME}$ at $600 \mathrm{~L} \mathrm{~m}^{-2} \mathrm{~h}^{-1}$ with a $10 \mu \mathrm{m}$ membrane as a function of stirring speed. The predicted droplet diameters are calculated using analytical model presented in the appendix $A$. 
A)

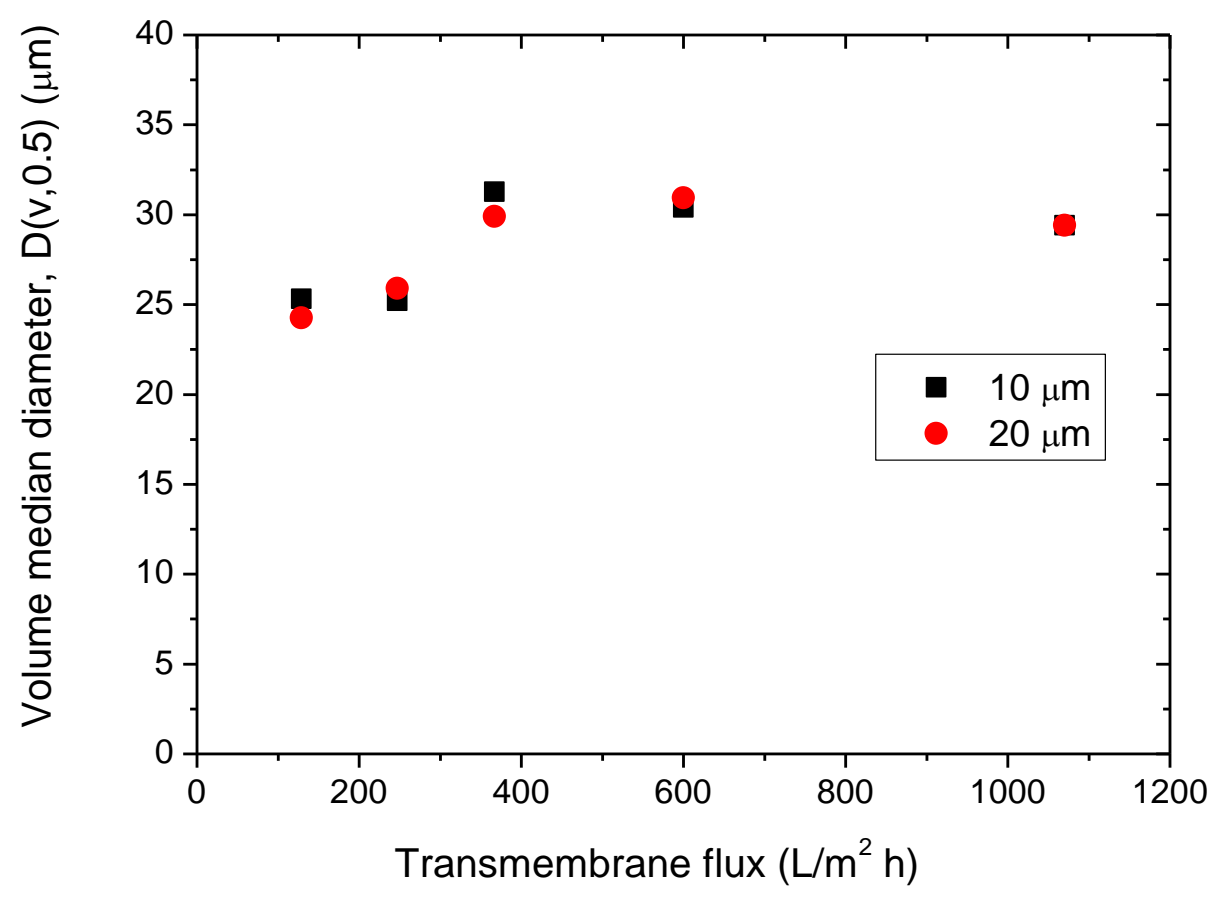

B)

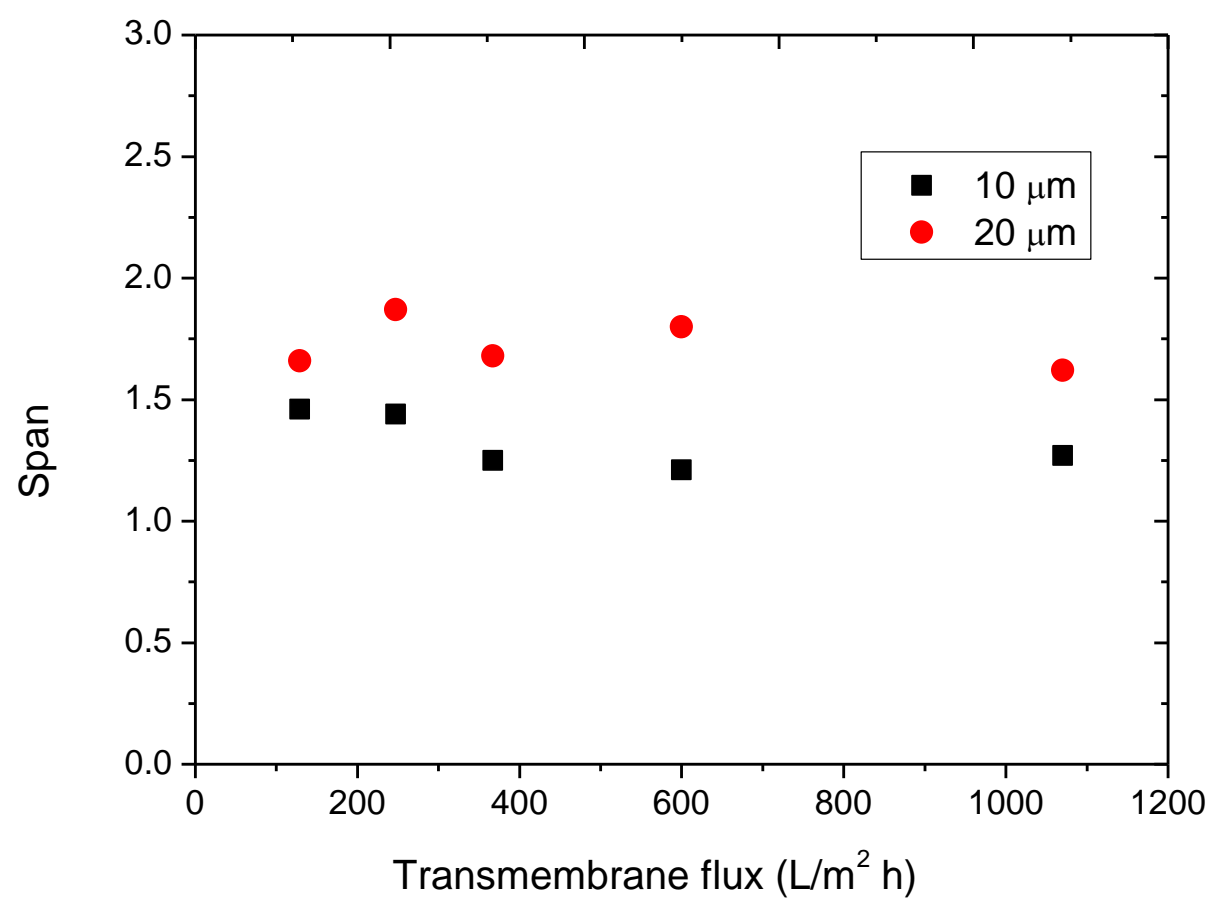

Figure 7. The effect of transmembrane flux on: $A)$ Volume median diameter, $D(v, 0.5)$ and $B)$ Span for the emulsions processed by direct ME at $620 \mathrm{rpm}$ with a 10 and $20 \mu \mathrm{m}$ membrane. 


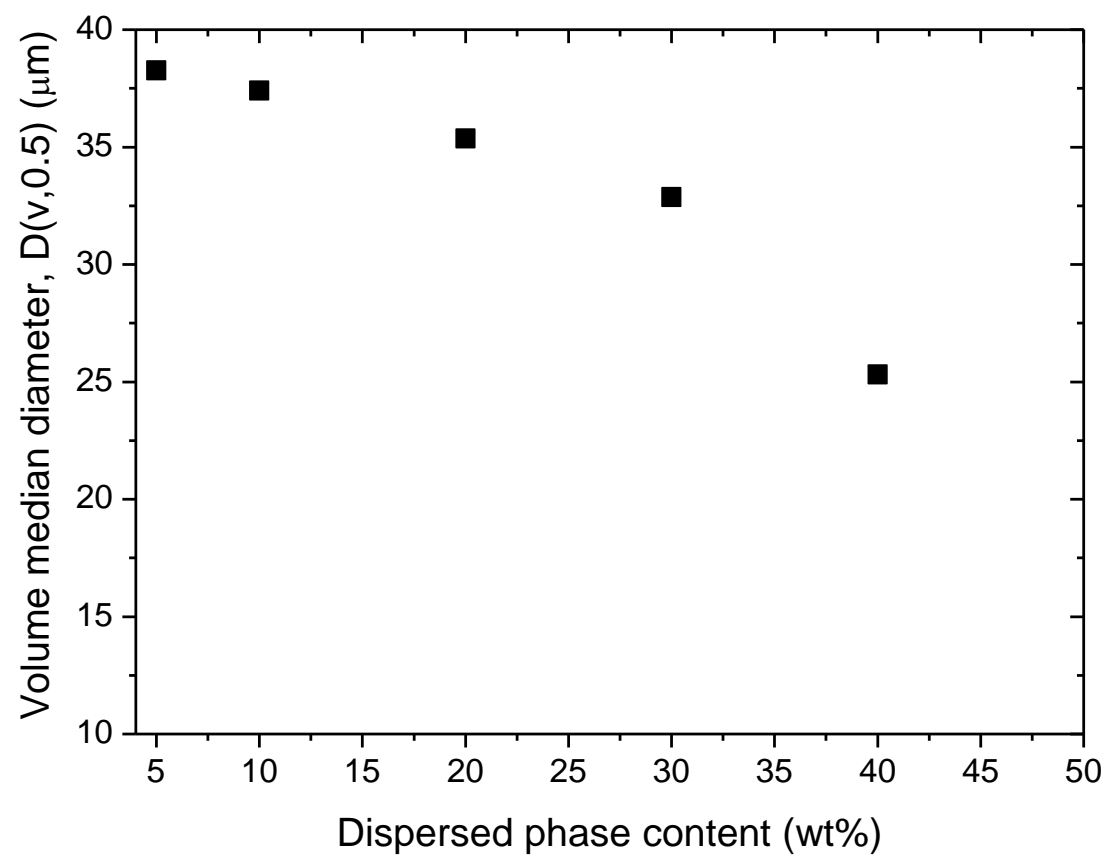

Figure 8. The effect of the dispersed phase content in the emulsions on the volume mean diameter, $\left(D(v, 0.5)\right.$ in direct ME at $129 \mathrm{~L} \mathrm{~m}^{-2} \mathrm{~h}^{-1}$ and $620 \mathrm{rpm}$ with $10 \mu \mathrm{m}$ membrane. The surfactant/oil ratio was kept at $0.10(\mathrm{w} / \mathrm{w})$ in all samples. 
(A)

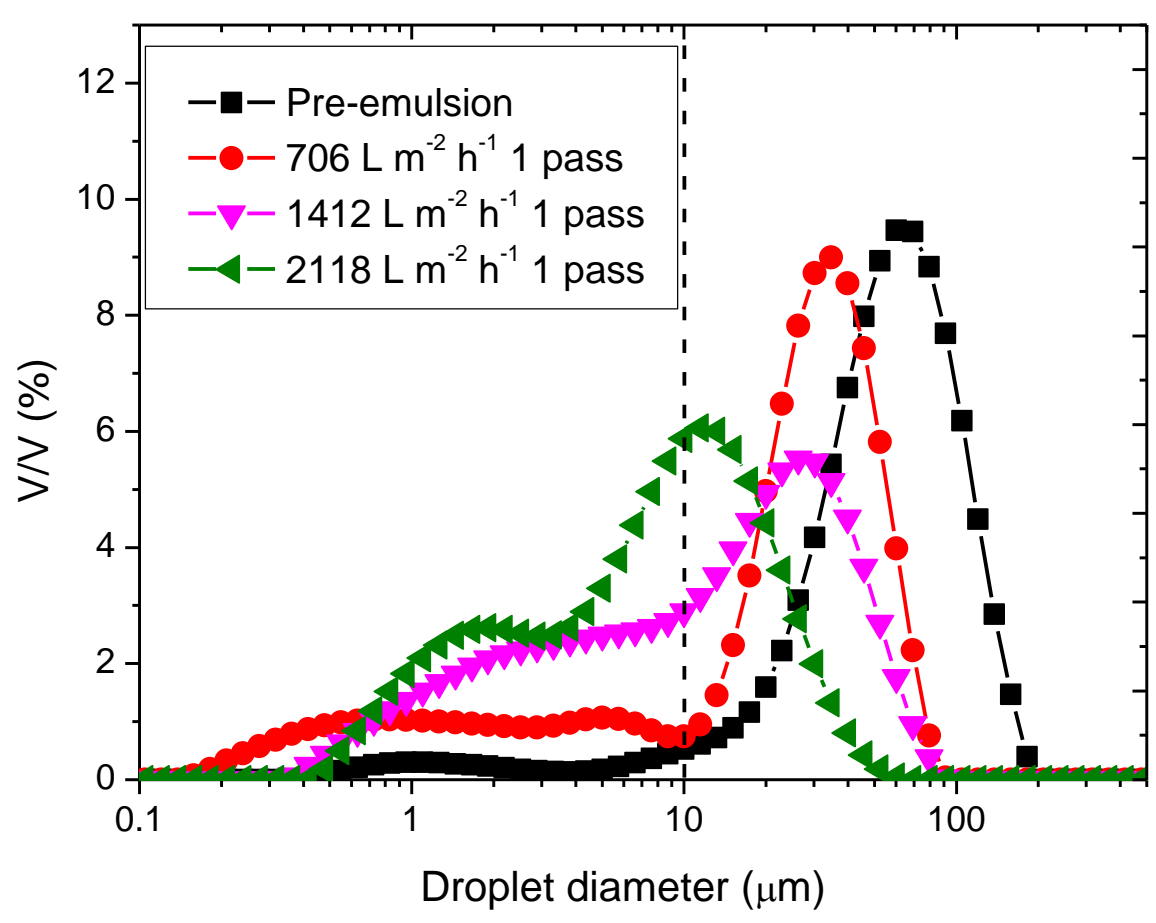

(B)

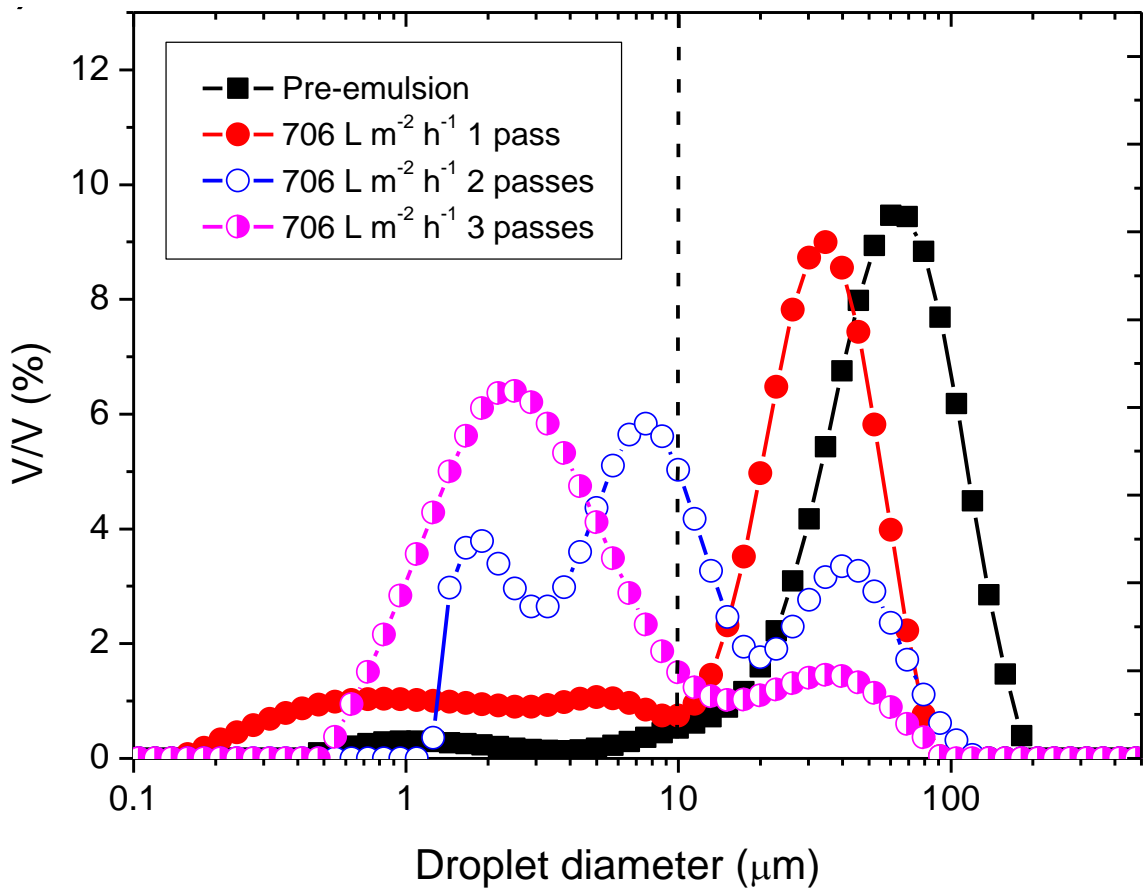

Figure 9. The effect of transmembrane flux (A) and number of membrane passes (B) on the PSD of the emulsions prepared by premix ME using a $10 \mu \mathrm{m}$ membrane. The location of the dashed line corresponds to the membrane pore diameter. 


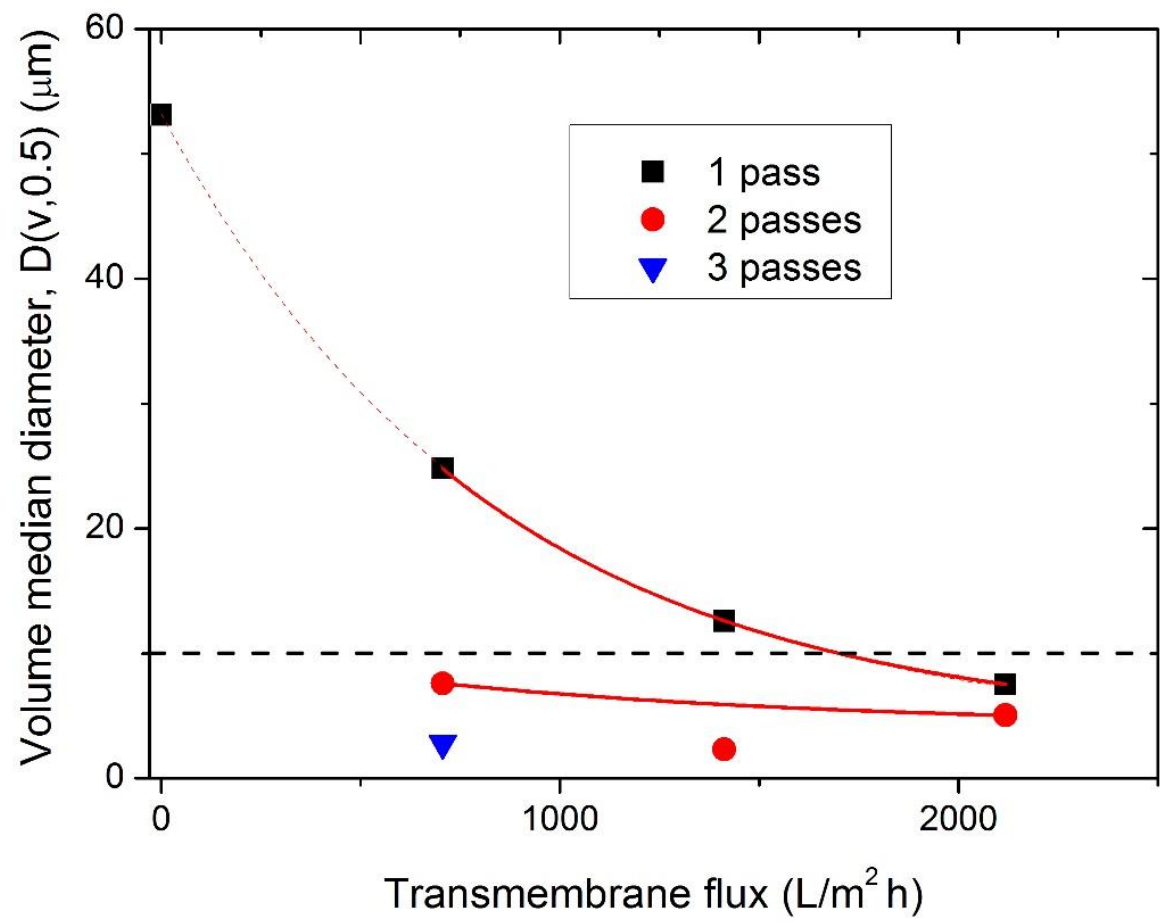

Figure 10. The effect of transmembrane flux and number of passes through the $10 \mu \mathrm{m}$ membrane on the volume median diameter of emulsions prepared by premix ME. 
(A)

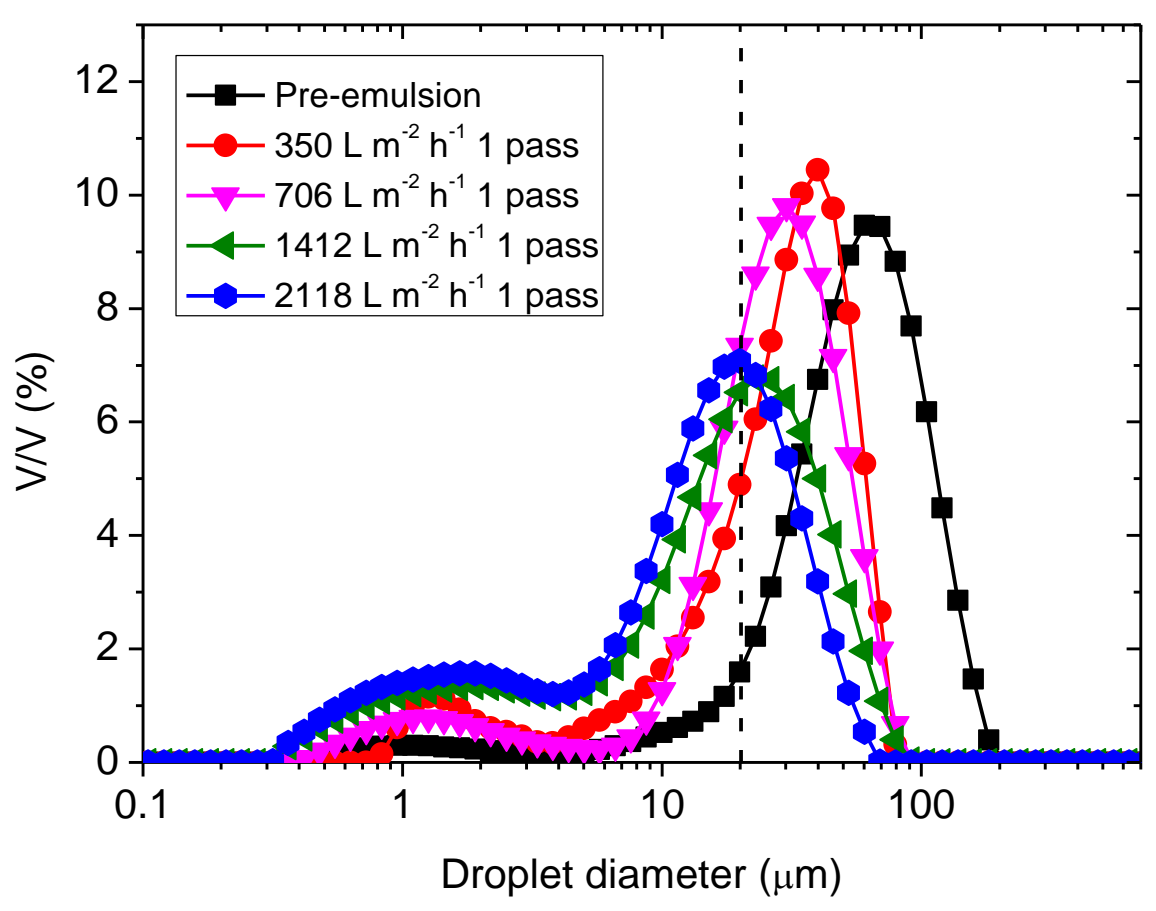

(B)

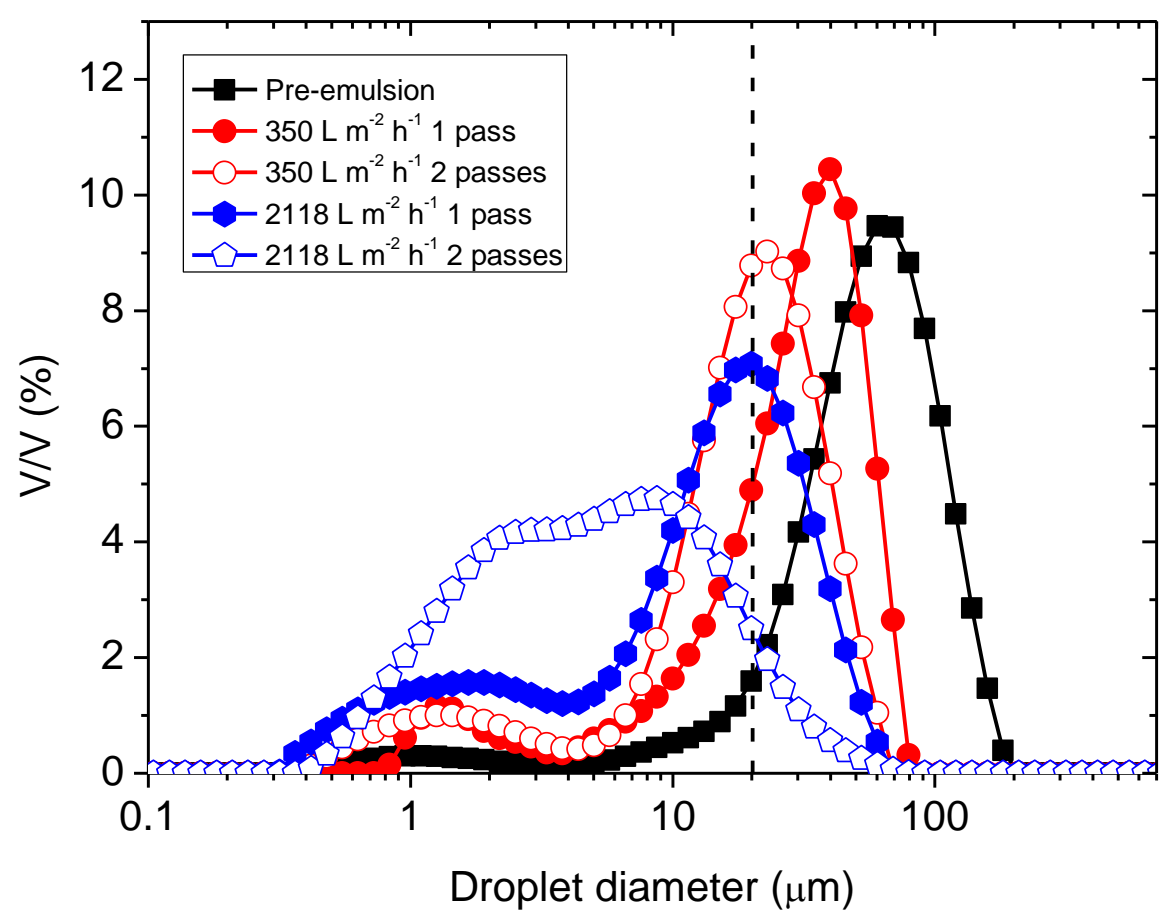

Figure 11. The effect of transmembrane flux $(A)$ and number of passes through the membrane (B) on the PSD of emulsions obtained by premix ME with the $20 \mu \mathrm{m}$ pore size membrane. 


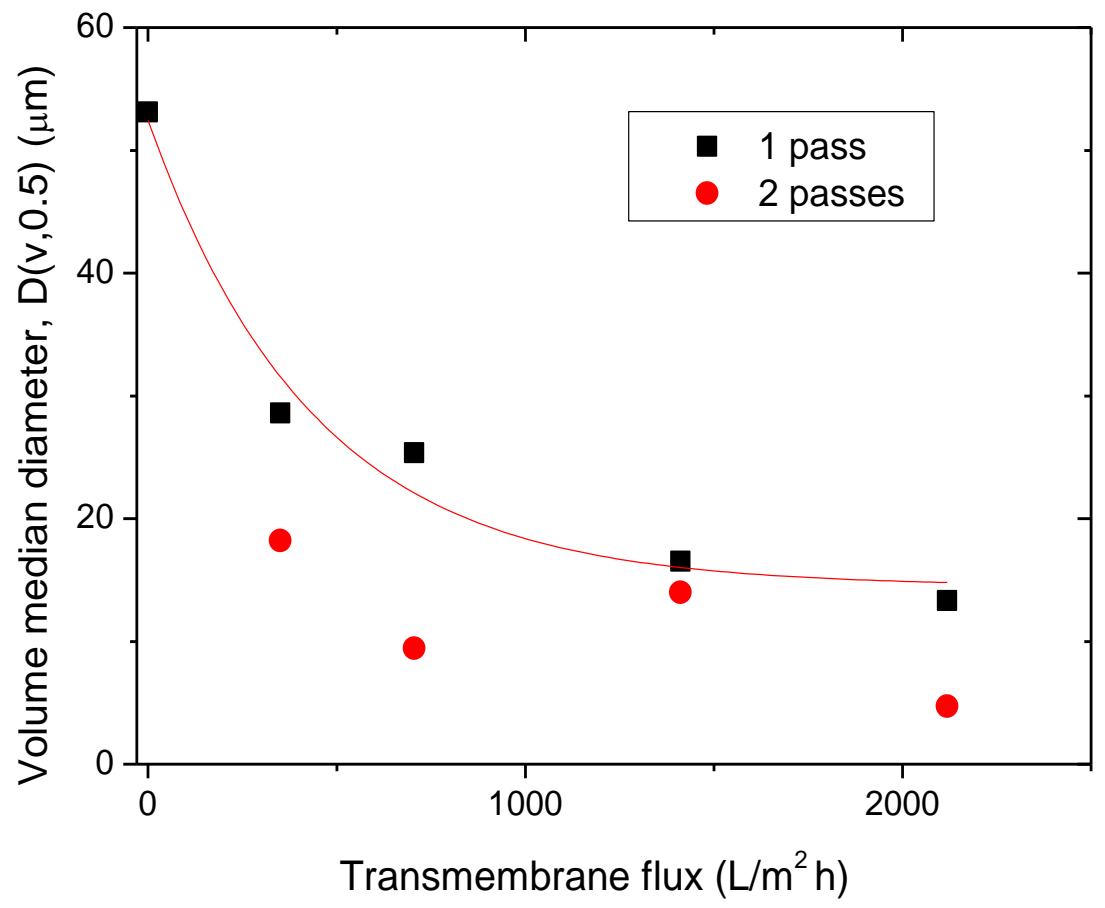

Figure 12. The effect of transmembrane flux and number of passes through the membrane on $\mathrm{D}(\mathrm{v}, 0.5)$ for emulsions obtained by premix ME using the $20 \mu \mathrm{m}$ pore size membrane. 


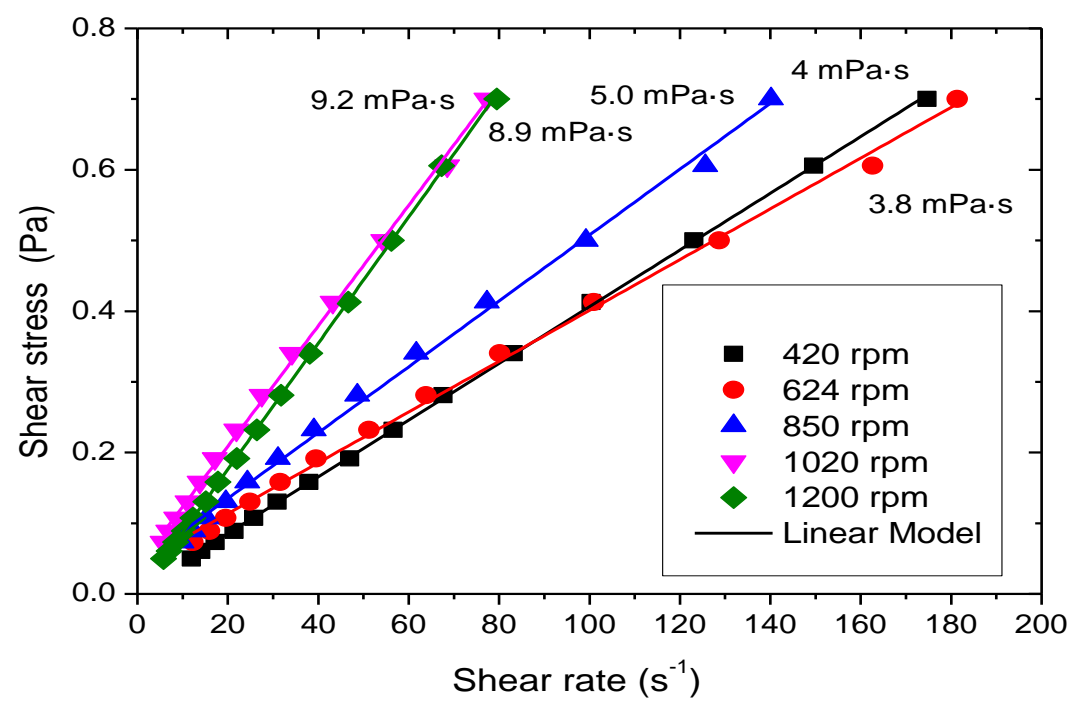

Fig. 13A. The effect of stirring speed on the flow curves for the emulsions produced by direct ME at $600 \mathrm{~L} \mathrm{~m}^{-2} \mathrm{~h}^{-1}$ using $10 \mu \mathrm{m}$ membrane. Straight lines are the best fit lines.

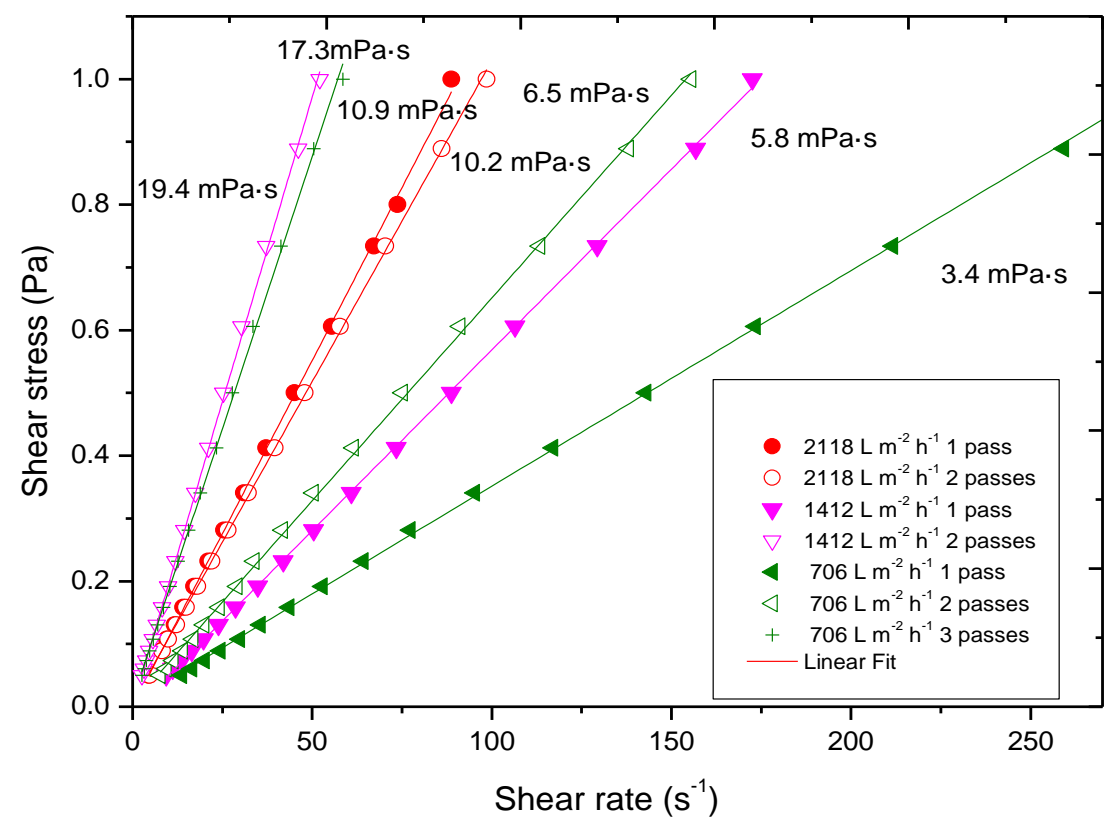

Fig. 13B. The effect of transmembrane flux on flow curves for the emulsions produced by premix ME using $10 \mu \mathrm{m}$ membrane. Straight lines are the best fit lines.

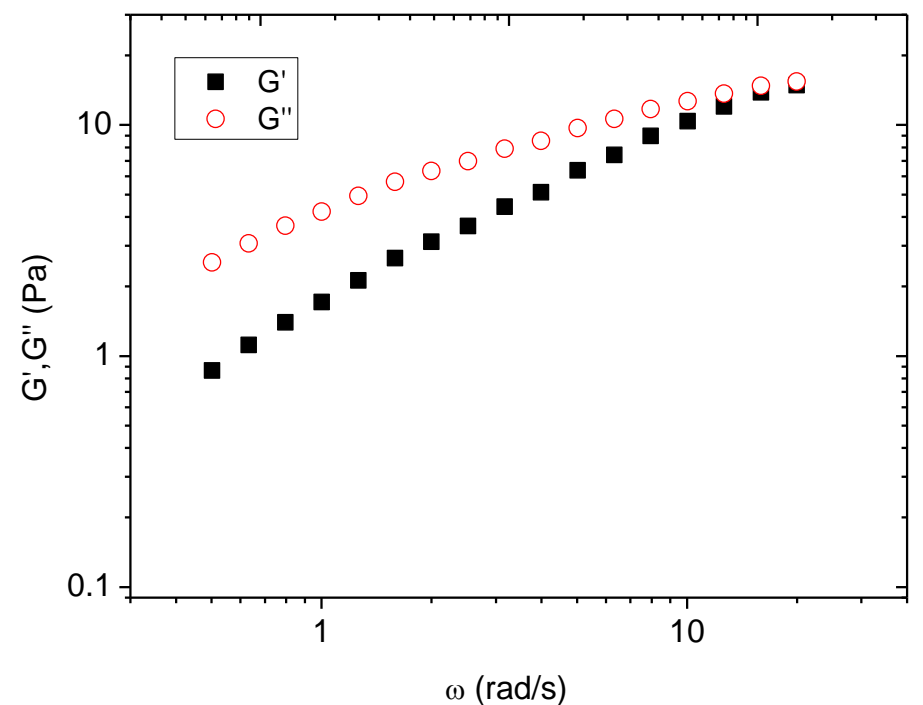

Figure 13C. Mechanical spectra for $40 \mathrm{wt} \%$ emulsion produced by direct ME at $129 \mathrm{~L} \mathrm{~m}^{-2} \mathrm{~h}^{-1}$ and 620 rpm using $10 \mu \mathrm{m}$ membrane. 


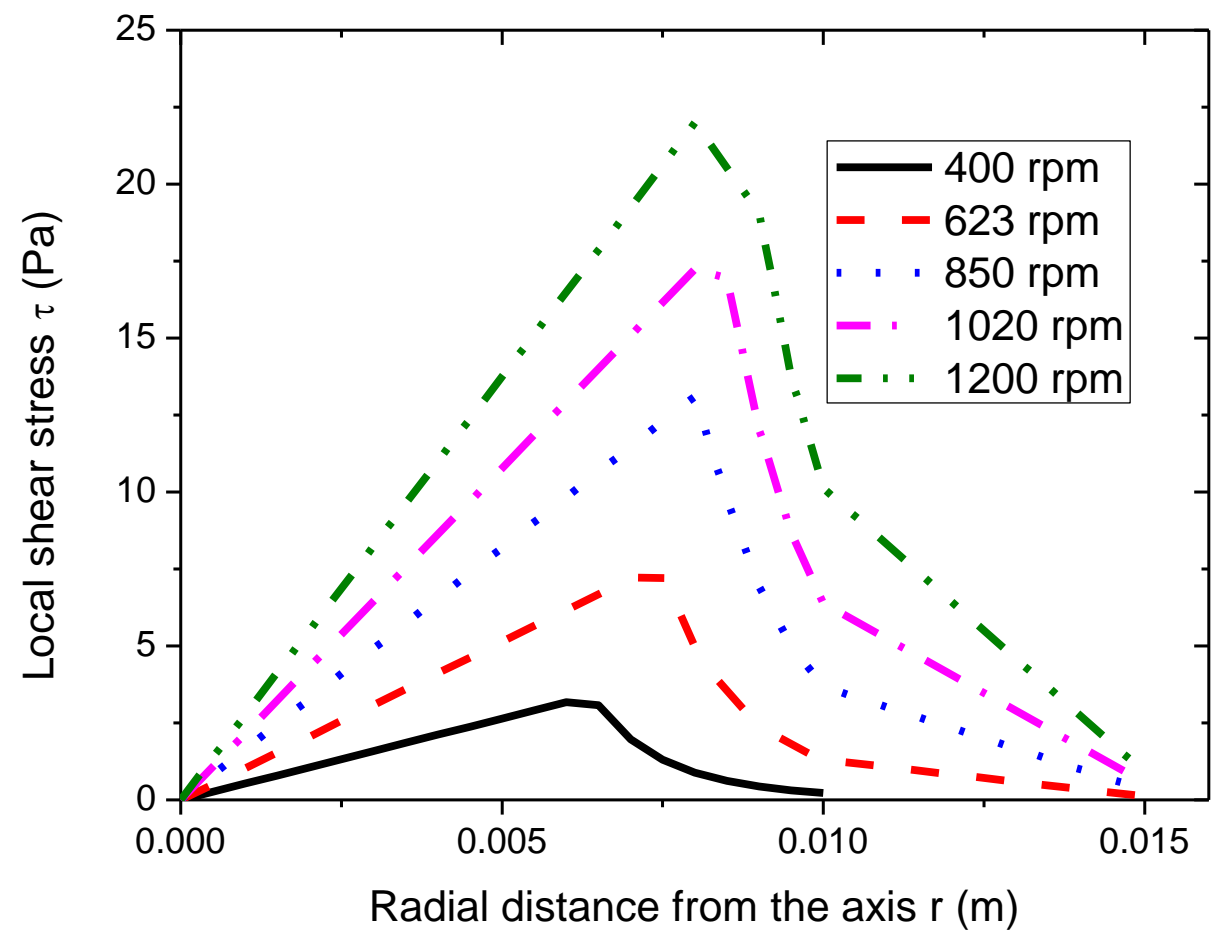

Figure 14. The variation of local shear stress over the membrane surface at different stirrer speeds for $30 \%$ emulsion, calculating using Eq. (3) or Eq. (4). 
Table 1. The effect of the ratio of AMD-10 and d-limonene in the dispersed phase on the volume median diameter and span for emulsions prepared by direct ME at 620 $\mathrm{rpm}$ and $600 \mathrm{~L} \mathrm{~m}^{-2} \mathrm{~h}^{-1}$.

\begin{tabular}{|c|c|c|c|c|}
\hline \multirow{2}{*}{$\begin{array}{c}\text { wt\% AMD-10 in } \\
\text { dispersed phase }\end{array}$} & \multicolumn{2}{|c|}{$10 \mu \mathrm{m}$ membrane } & \multicolumn{2}{c|}{$20 \mu \mathrm{m}$ membrane } \\
\cline { 2 - 5 } & $\mathrm{D}(\mathrm{v}, 0.5)$ & span & $\mathrm{D}(\mathrm{v}, 0.5)$ & span \\
\hline 0 & 45.5 & 0.9 & 69.3 & 1.1 \\
\hline 25 & 30.4 & 1.2 & 30.9 & 1.2 \\
\hline 35 & 21.7 & 1.8 & - & - \\
\hline
\end{tabular}


Table 2. The equilibrium interfacial tension between the aqueous and oil phase for different solvent ratios in the absence and in the presence of the used surfactant at $20^{\circ} \mathrm{C}$.

\begin{tabular}{|c|c|c|}
\hline \multirow{2}{*}{$\begin{array}{l}\text { AMD-10/d-limonene } \\
\text { mass ratio (wt/wt) }\end{array}$} & \multicolumn{2}{|c|}{ Interfacial tension $\left(\mathrm{mN} \mathrm{m}^{-1}\right)$} \\
\hline & no surfactant & $\begin{array}{c}3 \text { wt\% Levenol } \\
{ }^{\otimes} \text { C-201 }\end{array}$ \\
\hline $0 / 100$ & $40.0 \pm 1.3$ & $7.0 \pm 0.5$ \\
\hline $25 / 75$ & $7.0 \pm 0.4$ & $1.0 \pm 0.1$ \\
\hline $35 / 65$ & $4.0 \pm 0.3$ & - \\
\hline
\end{tabular}

